\title{
Review
}

\section{Halloysite Nanotubes: Smart Nanomaterials in Catalysis}

\author{
Marina Massaro (D), Renato Noto and Serena Riela *
}

Citation: Massaro, M.; Noto, R.;

Riela, S. Halloysite Nanotubes: Smart

Nanomaterials in Catalysis. Catalysts 2022, 12, 149. https://doi.org/

$10.3390 /$ catal12020149

Academic Editor: Enrique

García-Bordejé

Received: 6 January 2022

Accepted: 23 January 2022

Published: 25 January 2022

Publisher's Note: MDPI stays neutral with regard to jurisdictional claims in published maps and institutional affiliations.

Copyright: (C) 2022 by the authors. Licensee MDPI, Basel, Switzerland. This article is an open access article distributed under the terms and conditions of the Creative Commons Attribution (CC BY) license (https:// creativecommons.org/licenses/by/ $4.0 /)$.

\author{
Department of Biological, Chemical and Pharmaceutical Sciences and Technologies, University of Palermo, \\ Viale delle Scienze, Ed. 17, 90128 Palermo, Italy; marina.massaro@unipa.it (M.M.); renato.noto@unipa.it (R.N.) \\ * Correspondence: serena.riela@unipa.it
}

\begin{abstract}
The use of clay minerals as catalyst is renowned since ancient times. Among the different clays used for catalytic purposes, halloysite nanotubes (HNTs) represent valuable resources for industrial applications. This special tubular clay possesses high stability and biocompatibility, resistance against organic solvents, and most importantly be available in large amounts at a low cost. Therefore, HNTs can be efficiently used as catalysts themselves or supports for metal nanoparticles in several catalytic processes. This review reports a comprehensive overview of the relevant advances in the use of halloysite in catalysis, focusing the attention on the last five years.
\end{abstract}

Keywords: halloysite nanotubes; catalyst support; metal nanoparticles; covalent approach

\section{Introduction}

Over the past years, the world community devoted a great attention to environmental pollution, climate change, sustainable energy and so on. In this context, to answer needs at the global level, the scientific community's challenges are focused on the development of innovative approaches and strategies able to prevent the problems referred to above. Catalysis, and in particular a heterogeneous one, is fundamental in many industrial processes; indeed, the research devoted on the design of catalytic support, based on raw materials available at low cost and high recyclability nature, is a goal for the development of green reactions. A common strategy for enhancing the efficiency of heterogeneous catalysis is based on the use of catalysts that show high adsorption capacity, in which the reactants are well dispersed over their surface. Thus, a crucial point is the choice of nanomaterials that possesses a high specific surface area with uniform pore size.

Among the different materials that can be used for these purposes, clay minerals are one of the most promising.

The use of clay minerals for catalytic purposes has been renowned since ancient times. Clay minerals are phyllosilicate constituted by aluminum or magnesium, and depending on the extraction site, they also present, in their crystalline structure, small amounts of cations such as iron, chromium, nickel and so on. In addition, they are abundant, inexpensive, noncorrosive, and nonpolluting. Furthermore, when used as catalysts, clay minerals can be easily separated from the reaction mixture, allowing them to be recycled without a significant loss of activity.

The catalytic activity of clay minerals is related to their capacity to act as solid acids in either the Brønsted or Lewis sense as influenced by sample pretreatment and experimental conditions. They also possess the ability to displace some water molecules, physisorbed on their surfaces, with cations generating active centers which also explain their catalytic ability towards chemical reactions. Therefore, clay minerals are promising for heterogeneous catalysis.

Several studies reported that clay minerals played an important role in the origin of life, due to their ability to entrap and catalyzed reactions of small organic molecules that were at the base of early life. Indeed, it is found that the presence of clays and zeolites on earth was very important, since due to their charged ordered surfaces on which the sorption and 
oligomerization of reactants can occur, they could act as templates for prebiotic reactions. Since then, several efforts have been made to evaluate the use of clays as heterogeneous catalytic systems in several reactions. In addition, when appropriately modified, clay materials can themselves act as support for catalysts, bringing the benefits of heterogeneous catalysis to several reaction processes.

The clay minerals mostly used as catalysts are montmorillonite, kaolinite, palygorskite, smectite and sepiolite, and more recently halloysite [1].

The attention on the use of clay minerals as catalysts was pointed out in 1948, after a whole day meeting of the Clay Minerals Group of the Mineralogy Society [2]. At the beginning, clay minerals were mainly used as catalyst in the cracking of petroleum products [3] (Figure 1). In the following years, the research was focused on the use, among others, of montmorillonite as catalyst for amino acids and small peptides formation. Until 2002, the majority of published works were related to the use of clays as catalysts themselves, exploiting their intrinsic acidity or their cation-exchange properties. In this period, more papers started to deal with the application of kaolin group's clay minerals in catalysis, focusing on their use as cracking catalysts in petrochemical processing. These studies pointed out that the cracking activity of the clays is mainly related to their mineral compositions.

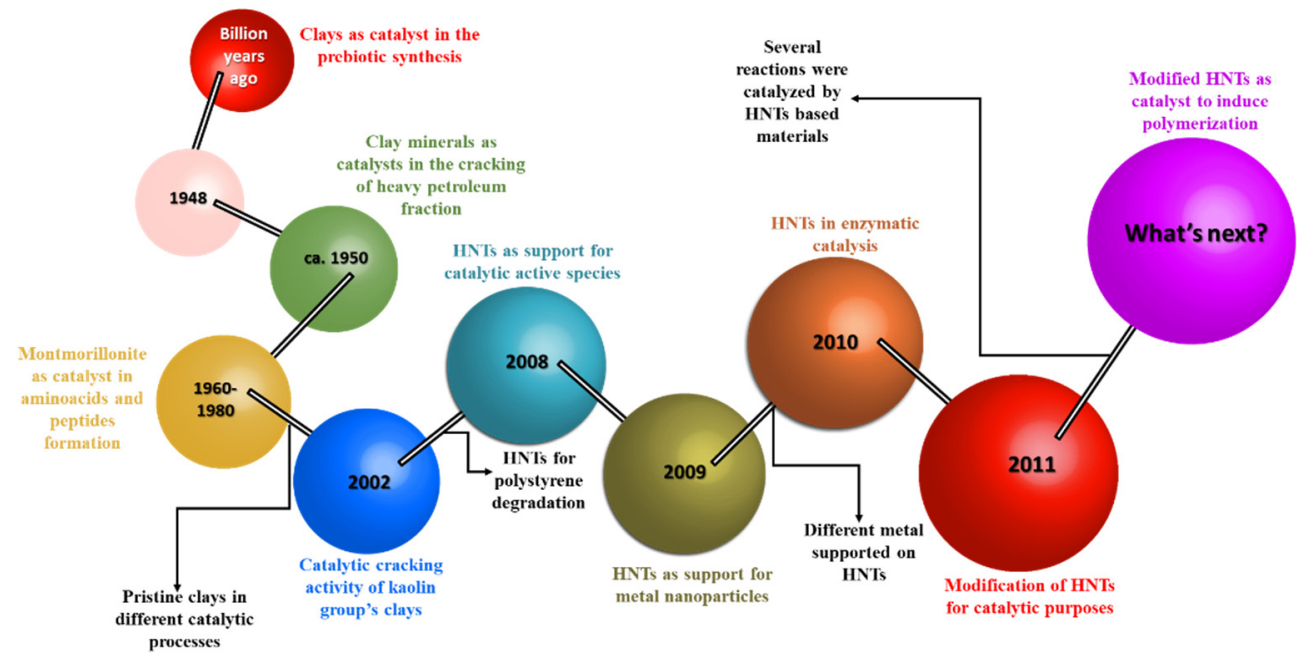

Figure 1. A brief timeline for the use of clay minerals as catalyst and in particular on the application of halloysite nanotubes (HNTs).

Since 2003, among the different clay minerals belonging to the kaolin group, halloysite started to be considered a good catalytic material, when it was hypothesized its use as catalyst in polystyrene degradation. Afterwards, several efforts have been made to improve the performance of halloysite itself for catalytic purposes, or as support for catalytic activity species (2007) and/or metal nanoparticles (2009). In addition, it also explored the possibility to modify the clay to obtain novel nanomaterial, which showed interesting catalytic features.

The aim of this review is to deliver a comprehensive overview of the relevant advances in the use of halloysite in catalysis, focusing the attention on the last five years. After a brief paragraph about the physico-chemical properties of halloysite and an historical background, the first section of the review will be focused on the use of HNTs as catalyst itself or modified by supramolecular and covalent approaches for support of catalytic active species. The second one will address HNTs' utilization as support for metal catalysts. For each section, an overview of improvements led by HNTs, synthesis of catalysts and reaction mechanism will be also considered.

Finally, a short paragraph will be devoted on the future perspectives about the use of the clay in the catalytic field. 


\section{Physico-Chemical Features of Halloysite Nanotubes}

Halloysite is a natural phyllosilicate belonging to the kaolin group with Al:Si in 1:1 ratio. Conversely to the platy kaolin, the different HNTs aluminosilicate layers, due to a misfit existing between them, tend to roll up into a tubular form, which causes halloysite to naturally be found in the predominant form of nanotubes. The reason of this peculiar morphology was ascribed to some natural process occurring during the synthesis. Halloysite nanotubes (HNTs) deposits are, indeed, widely found in soils of regions where climate conditions are ranging from subtropical to wet tropical, which show the presence of weathered rocks and soil generated from volcanic ashes. Countries such as Turkey, France, New Zealand and China are very rich of halloysite deposits, in which the clay possesses $90-98 \%$ of tubular structure.

From a chemical point of view, halloysite nanotubes present a chemical formula of $\mathrm{Al}_{2} \mathrm{Si}_{2} \mathrm{O}_{5}(\mathrm{OH})_{4} \cdot \mathrm{nH}_{2} \mathrm{O}$, where $n$ represents their hydration state. HNTs can be thus classified as hydrated HNTs $\left(\mathrm{Al}_{2} \mathrm{Si}_{2} \mathrm{O}_{5}(\mathrm{OH})_{4} \cdot 2 \mathrm{H}_{2} \mathrm{O}\right)$ which present an interlayer $\mathrm{d}_{001}$ spacing of $10 \AA$, and dehydrated $\left(\mathrm{Al}_{2} \mathrm{Si}_{2} \mathrm{O}_{5}(\mathrm{OH})_{4}\right)$ with $7 \AA \mathrm{d}_{001}$ spacing.

Structurally, halloysite nanotubes are composed by 10-15 aluminosilicate bilayers, with a spacing of approximately $0.72 \mathrm{~nm}$; this arrangement produces an external surface rich in siloxane $(\mathrm{Si}-\mathrm{O}-\mathrm{Si})$ groups and an inner one comprising a gibbsite-like array of aluminol $(\mathrm{Al}-\mathrm{OH})$ groups. Furthermore, the rolling process makes that some structural defects are also present at the HNTs edges in the form of some Al-OH and $\mathrm{Si-OH}$ groups (Figure 2). Because of the different chemical composition, the tubes undergo ionization in aqueous media in an opposite way, generating tubes with inner and outer surfaces oppositely charged [4]. This charge separation occurs in water within a wide $\mathrm{pH}$ range from 3 to 8 [5]. The tubes have a length in the range of $0.2-1.5 \mu \mathrm{m}$, while the inner and outer diameters are in the ranges of $10-30 \mathrm{~nm}$ and $40-70 \mathrm{~nm}$, respectively [6-8]. The modification of the inner and/or outer surfaces opens different strategies to introduce new properties on HNTs expanding their application fields. It has been indeed proposed the use of HNTs as fillers in polymeric matrices [9-13], flame retardants [14], nanoadsorbents for environmental remediation [15-22], and due to their biocompatibility, as drug carrier and delivery systems [23-33]. Furthermore, suitable modifications confer to HNTs additional properties such as luminescence [34] or fluorescence tracking ability [35], which of course allow us to utilize the obtained nanosystems for bioimaging.

a

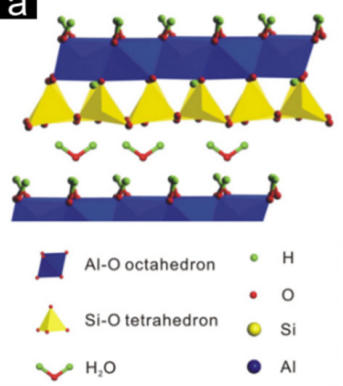

b

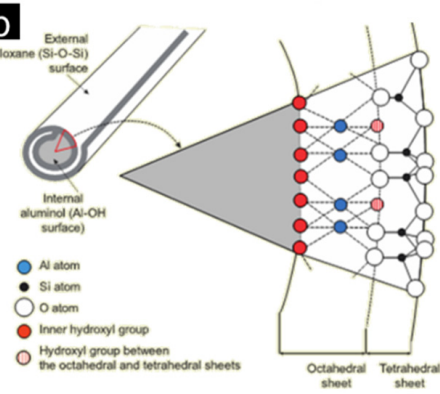

TEM image of halloysite

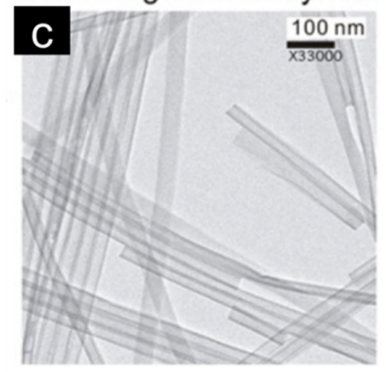

AFM image of halloysite

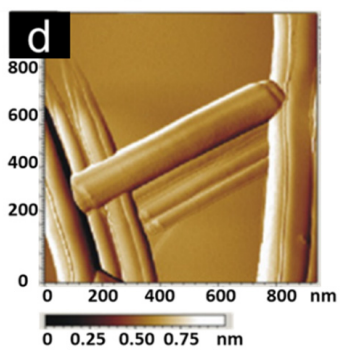

Figure 2. (a,b) HNTs crystal morphology and atomic structure; (c,d) TEM and AFM images of HNTs. Adapted with permission from ref. [36,37]. Copyright 2015 Elsevier and Copyright 2009 Elsevier. 


\section{Halloysite in Catalysis}

\subsection{The Beginning}

Halloysite nanotubes, due to their hollow tubular structure, opposite charged surfaces and high specific surface areas, are a promising tool for adsorption of chemical species. Different studies reported that HNTs possess remarkable adsorption ability towards both anionic or cationic species by electrostatic attraction interactions with the surfaces and neutral ones, which are selectively loaded into the lumen by hydrophobic effects or hydrogen bonding interactions [38]. The adsorption ability was extensively investigated for biological purposes, as well as for the HNTs use in environmental remediation [39]. For catalytic purposes, this aspect is also very important. The ability to adsorb reactants onto HNTs surfaces makes this clay highly active as catalyst in several chemical processes, since it allowed a greater local concentration of reactants or catalytic active species (as for examples metal nanoparticles) with a consequent improvement of the catalytic performances.

The extensive use of halloysite as catalyst started in 2004, when acid-treated HNTs were used in the degradation of polystyrene into fuel oils [40]. The obtained results showed that the nanomaterial was promising with a selectivity to aromatics over than $99 \%$.

In 2008, Nakagaki et al. reported one of the first examples of immobilization of catalytic active species onto HNTs [41]. Their work was focused on the anionic and cationic metalloporphyrins immobilized into HNTs/nanoscrolls for hydrocarbon oxidation. The metalloporphyrins were immobilized by two different methods: (i) under pressure; or (ii) under stirring/reflux conditions. The best immobilization rate $(100 \%)$ for both the anionic iron(III) porphyrin and the cation one was achieved via a pressurized system. Catalytic studies, based on the oxidation of cyclooctene, $n$-heptane and cyclohexane, in the presence of iodosylbenzene as oxygen donor, showed that the use of HNTs was promising, since it increased alcohol yields and decreased the ketone ones, conversely to the unsupported porphyrin. This selectivity was explained taking into account that the solid support controls the access of the substrate to the active site, or alternatively, controls the access of iodosylbenzene to generate the oxidizing species.

Some years later, the same authors [42] studied the effect of HNTs pretreatment for similar application. Pre-calcinated HNTs (meta-HNTs) were used for the immobilization of the anionic iron(III) porphyrin [Fe(TDFSPP)] (Fe-Por), and tested as catalysts in the heterogeneous oxidation of several substrates (namely cyclooctene, cyclohexane or nheptane), using iodosylbenzene as oxidant agent. Catalytic tests showed that the Fe-Por catalyst possesses good catalytic performance resulting in appreciable turnover numbers, in comparison with the non-supported one. As, for example, in the case of cyclooctene oxidation (Table 1), the high yield and turnover number achieved suggested a relevant role of the HNTs support; it was indeed hypothesized that the immobilization of FePor onto the solid support surface left the catalytic site still accessible to the reactants. Therefore, the contact between the catalytic active species is facilitated, favoring product formation. In addition, the developed heterogeneous catalytic system showed good recyclability without significantly leaching porphyrin after several consecutive runs (Table 1, Entry 3).

Table 1. Cyclooctenoxide yields achieved in the oxidation of cyclooctene by PhIO catalyzed by Fe-Por and FeMeta-HNTs [42] ${ }^{\text {a }}$. Adapted with permission from ref. [43].

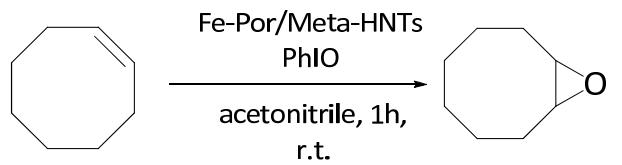

\begin{tabular}{ccccc}
\hline Entry & Catalyst & Cycle & Yield (\%) & TON $^{\mathbf{b}}$ \\
\hline 1 & Fe-Por-Meta-HNTs & 1 & 85 & 38.7 \\
2 & Fe-Por-Meta-HNTs & 2 & 85 & 38.7 \\
3 & Fe-Por-Meta-HNTs & 3 & 85 & 38.7 \\
4 & Fe(TDFSPP) & 1 & 85 & 5 \\
\hline
\end{tabular}


Table 1. Cont.

\begin{tabular}{ccccc}
\hline Entry & Catalyst & Cycle & Yield (\%) & TON $^{\mathbf{b}}$ \\
\hline 5 & none & 1 & 10 & 0.1 \\
6 & Meta halloysite & 1 & 30 & $<0.01$ \\
\hline
\end{tabular}

a Reaction conditions: Catalyst:PhIO:substrate, molar ratio 1:20:2000. ${ }^{\mathrm{b}}$ TON: turnover number, expressed as mol of product $/ \mathrm{mol}$ of catalyst.

In 2010, Zhang et al. loaded, for the first time, some commonly used industrial enzymes into HNTs lumen. In particular, this study investigated the effects of HNTs on the $\alpha$-amylase and urease immobilization [44]. The enzymes were loaded by a simple physical adsorption process, and the nanomaterials obtained were tested for catalytic purposes. It was found that the use of HNTs is advantageous to overcome enzyme utilization limitations, such as inactivation with temperature. Experimental results showed that by heating the nanomaterials HNTs/enzymes for $60 \mathrm{~min}$, more than $80 \%$ of enzymatic activity was retained, and about $90 \%$ was maintained after 15 days of storage.

In 2012, $\mathrm{Co}_{3} \mathrm{O}_{4}$ nanoparticles were supported on pristine HNTs by Li et al. [45] to develop catalytic materials for application in the Fischer-Tropsch reaction. Two different methods were considered for the Co NPs stabilization, namely double-solvents and wet impregnation methods. It was demonstrated that the $\mathrm{Co}_{3} \mathrm{O}_{4}$ particles were stabilized by the HNTs support, therefore preventing their migration and agglomeration due to size-induced effects, when the double-solvent method was used for the catalyst synthesis. The obtained HNTs catalyst showed higher $\mathrm{CO}$ conversion and $\mathrm{C}_{5+}$ selectivity for FischerTropsch synthesis.

Since 2011, some authors started to exploit the covalent modification of HNTs to achieve innovative supports for catalytic species. For example, Sepúlveda-Escribano et al. modified the HNTs external surface with aminosilanes bearing two or three amino groups, respectively, obtaining HNT-based supports for application in the heterogeneous atom transfer polymerization of methyl methacrylate (MMA) into poly(methylmethacrylate) (PMMA), using $\mathrm{CuBr}$ as a catalyst [46]. The grafted silanes acted as ligands for $\mathrm{CuBr}$, as well as a catalyst for the heterogeneous polymerization. In addition, the modification of HNTs led to a better control of the polymerization, depending on the grafted silane (Figure 3).

(a)

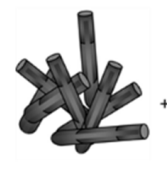

$\begin{array}{r}\mathrm{MeO} \\ +\quad \mathrm{MeO} \cdot \mathrm{Si} \\ \hline\end{array}$
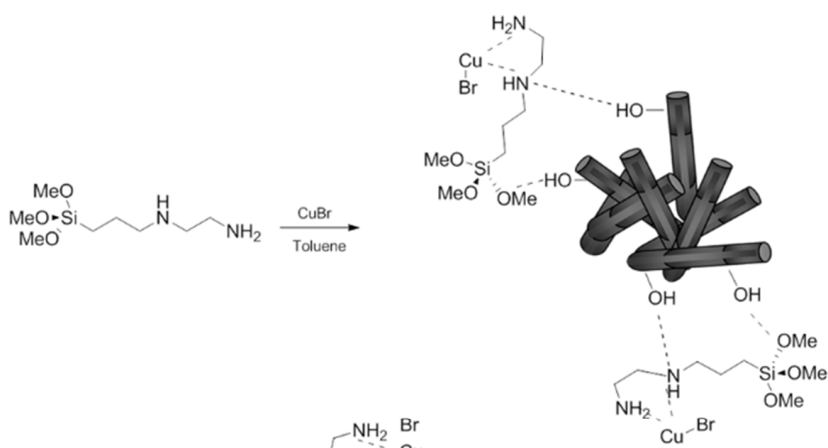

(b)

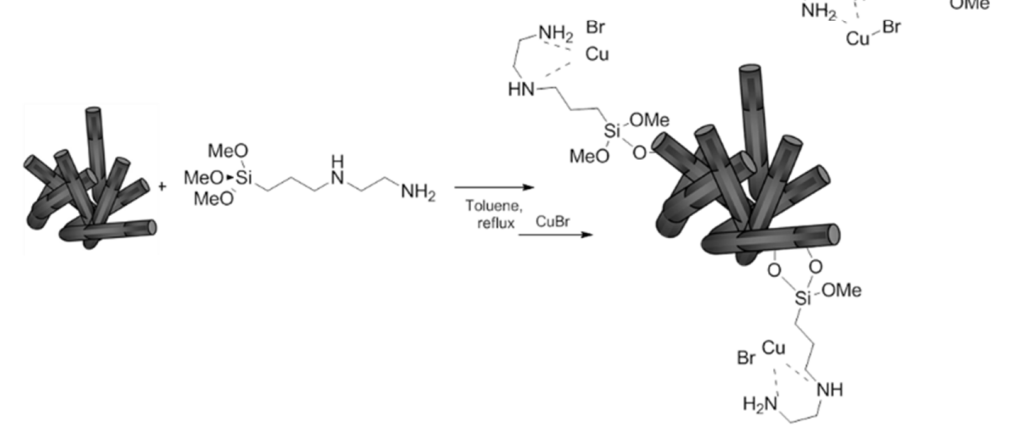

Figure 3. (a) Physisorption of $\mathrm{CuBr}$ /silane catalyst onto HNTs; (b) modification of HNTs surface by silane groups before to formation of the catalyst. Adapted with permission from ref. [46]. Copyright 2011 Elsevier. 
Similarly, the following year, Jiang et al. modified HNTs surface with N-(2-aminoethyl)3-aminopropyltrimethoxysilane to introduce a suitable functional group which was further modified by alkylation. The authors used the obtained support for $\left\{\mathrm{PO}_{4}\left[\mathrm{~W}(\mathrm{O})\left(\mathrm{O}_{2}\right)_{2}\right]_{4}\right\}^{3-}$ immobilization, and employed it as catalyst for the epoxidation of soybean oil [47].

Poly(4-vinylpyridine) was anchored by an in situ polymerization on HNTs' external surface, previously modified with $\mathrm{N}-\beta$-aminoethyl- $\gamma$-aminopropyl trimethoxysilane $(\mathrm{KH}-$ 792), to obtain a solid support for Ag nanoparticles immobilization [48]. Once synthetized, the nanomaterial was used as catalyst in the photodegradation of methylene blue in the presence of tea polyphenols as reducing agents. The synthetized nanocatalyst showed a good catalytic performance and high adsorption capacity; indeed, within $60 \mathrm{~min}$, nearly $90 \%$ of dye had been photocatalytically decomposed.

In these years, different approaches to immobilize Ru NPs onto the HNTs surfaces were also proposed. In the first method, $\mathrm{RuCl}_{3}$ was loaded onto halloysite by the wet impregnation method and the subsequent metal reduction at $450{ }^{\circ} \mathrm{C}$ [49]. Conversely, another study reported the stabilization of preformed Ru NPs obtained by polyol reduction [50]. The HNT-supported Ru NPs were used as catalysts for the oxidation of CO in a $\mathrm{H}_{2}$-rich atmosphere (PROX). The catalytic activities of the two catalysts were evaluated as $\mathrm{CO}_{2}$ selectivity and percentage of $\mathrm{CO}$ conversion. It was found that the immobilization of preformed metal NPs presented higher $\mathrm{CO}_{2}$ selectivity and $\mathrm{CO}$ conversion than the counterpart obtained by traditional wet impregnation.

In 2014, it was reported the HNTs modification with thiol silanes which were subse-

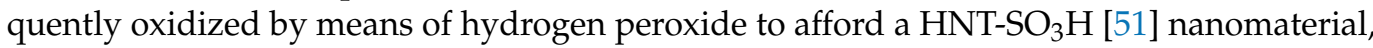
which acted as an acid-chromic chloride bi-functionalized catalyst for the one-pot conversion of cellulose to 5-hydroxymethyl furfural in ionic liquid as solvent.

\subsection{From 2017 to Nowdays}

\subsubsection{Catalytic Activity of Modified HNTs}

Pristine and amino modified HNTs were used, for the first time, as a catalyst for production of $\mathrm{H}_{2}$ from $\mathrm{NaBH}_{4}$ methanolysis [52,53]. Firstly, the HNTs external surface was modified, with several organic molecules bearing a different number of amine group, followed by their protonation by $\mathrm{HCl}$ treatment. Catalytic experiments showed that the performances of the synthetized nanomaterials are proportional to the number of amino groups introduced onto HNTs, with the higher activity found for the polyethylene imine-modified HNTs with an $\mathrm{H}_{2}$ generation rate (HGR) value of $4020 \mathrm{~mL} \mathrm{~min}^{-1} \mathrm{~g}^{-1}$ in comparison to pristine HNTs, which showed an HGR value of $640 \mathrm{~mL} \mathrm{~min}^{-1} \mathrm{~g}^{-1}$ at $298 \mathrm{~K}$. Furthermore, the nanomaterials showed promising recyclability properties for at least five consecutive runs.

In another work, pristine $\mathrm{HNTs}$ pre-treated with $\mathrm{HCl}$ were successfully employed as catalyst in the condensation of an allyl alcohol isopulegol with aldehydes to obtained chromene-based molecules, which possess a broad spectrum of biological activity [54]. Different experimental conditions were considered, and the results showed that the reactions are strictly influenced by halloysite drying temperature (Table 2).

It was found that the $4 \mathrm{R} / 4 \mathrm{~S}$ isomers ratio increased when the drying temperature was set around $150{ }^{\circ} \mathrm{C}$, and with the decreasing of the acidity of the catalyst. Therefore, the authors proposed that, for the formation of the $4 \mathrm{R}$-isomer, the presence of water molecules is crucial, such as those present at the ends of the nanotubes, which act as weak Brønsted acid sites.

To better understand the role of HNTs in the Prins reaction, the same authors thoroughly investigated the reaction between (-)-isopulegol reaction with thiophene-2-carbaldehyde by varying a series of experimental parameters (HNTs acid treatment conditions, catalyst loading, reaction temperature and initial concentration of substrates) [55]. The best experimental conditions were established as a pretreatment of $\mathrm{HNTs}$ with $5 \% \mathrm{HCl}$, a reaction temperature of $40{ }^{\circ} \mathrm{C}$ with an initial concentration of reactants of $0.5 \mathrm{~mol} \mathrm{~L}^{-1}$ and air-dry state of the catalyst. By adopting these conditions, the authors obtained an unexpected 
high yield (ca. $80 \%$ ) of 4 R-diastereomer, value that was comparable to that for the sum of both isomers on a commercial K-10, widely used for synthesis of chromene compounds based on terpenoids.

Table 2. Conversion of isopulegol ${ }^{\mathrm{a}}$ and product selectivity ${ }^{\mathrm{b}}$.

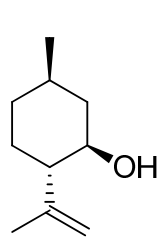

1

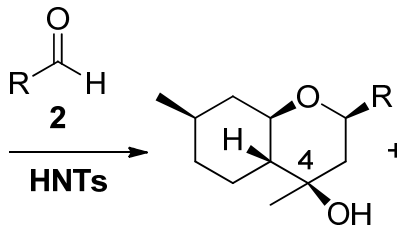

4R-3

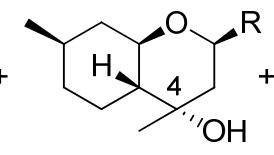

4S-3<smiles>[R]C1C=C(C)C2=CC[C@@H](C)C[C@H]2O1</smiles>

4

\begin{tabular}{|c|c|c|c|c|c|c|c|}
\hline \multirow{2}{*}{ HNTs Drying Temperature $\left({ }^{\circ} \mathrm{C}\right)$} & \multirow{2}{*}{ Mass Loss ( $\%)$} & \multirow{2}{*}{ Conversion (1) (mol\%) } & \multicolumn{4}{|c|}{ Selectivity (mol\%) } & \multirow{2}{*}{$4 R / 4 S$} \\
\hline & & & 3 & $4 R-3$ & $4 S-3$ & 4 & \\
\hline 20 (air dried) & 0 & 83.4 & 91.5 & 79.3 & 12.2 & 3.9 & 6.5 \\
\hline 50 & 2.0 & 98.3 & 87.3 & 74.8 & 12.8 & 6.5 & 5.8 \\
\hline 105 & 4.2 & 98.4 & 85.4 & 72.1 & 13.3 & 6.1 & 5.4 \\
\hline 150 & 5.1 & 99.1 & 80.3 & 64.5 & 15.8 & 6.6 & 4.1 \\
\hline 200 & 9.0 & 99.2 & 77.7 & 61.8 & 15.9 & 7.5 & 3.9 \\
\hline 350 & 9.4 & 95.1 & 76.3 & 59.6 & 16.7 & 7.2 & 3.6 \\
\hline
\end{tabular}

${ }^{a}$ Conversion of aldehyde is the same of isopulegol. ${ }^{b}$ Conditions: reaction with thiophene-2-carbaldehyde over HNTs, solvent-free, $1 \mathrm{~h}, 25^{\circ} \mathrm{C}$.

The same Prins reaction using ketons instead of alheydes was also studied in the presence of acid-treated HNTs [56]. In this case, the solvent-free reactions under mild conditions $\left(30^{\circ} \mathrm{C}\right)$ showed a chromenol selectivity of up to $77 \%$, value a once again significantly higher than that obtained on $\mathrm{H}-\mathrm{K}-10$ and $\mathrm{I}_{2}$ in the presence of methylene chloride as solvent.

Most recently, the condensation of $p$-menta-1,8-diene-5,6-diol 1 with decanal on acidmodified HNTs, to obtain the hexahydro-2H-chromene-4,8-diol 2 which possesses a high analgesic activity, was also investigated (Figure 4) [57].<smiles>C=C(C)[C@H]1CC=C(C)C(O)[C@@H]1O</smiles>

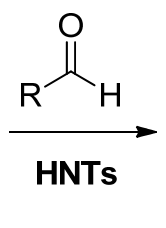

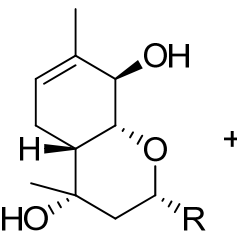

4S-2<smiles>[R]C1CC(C)(O)C2(C)CC=C(C)C(O)C2O1</smiles>

4S-2<smiles></smiles>

3

Figure 4. Condensation reaction of $p$-menta-1,8-diene-5,6-diol 1 with decanal.

In comparison to other clays, the use of HNTs led to an increase in the total yield of the corresponding hexahydro- $2 \mathrm{H}$-chromene-4,8-diols 2 and higher $4 \mathrm{~S} / 4 \mathrm{R}$ isomers ratio. The observed increase in the selectivity toward the $4 \mathrm{~S}$ isomers in this kind of reactions allowed to conclude the HNTs utilization is promising for the synthesis of pharmaceutical compounds.

A step forward on the use of HNTs as catalyst in the Prins reaction was made some years later by the modification of halloysite surface with organosulfonic acid. To achieve this goal, the authors covalently modified HNTs' external surface by adopting two different strategies: (i) direct sulfonation with chlorosulphonic acid; and (ii) one-pot organosilylation with 2-(4-chlorosulfonylphenyl)ethyltrimethoxysilane [58]. The nanomaterials were tested as catalysts in the Prins cyclization of (-)-isopulegol with benzaldehyde.

Recently, acid-treated HNTs were used as catalyst for the reaction of 2-carene with anisaldehyde (4-methoxybenzaldehyde), chosen as a model for isobenzofuran derivatives preparation [59]. The acid-treated HNTs turned out to be an efficient catalyst reaching the highest selectivity to isobenzofurans (70.9\%), in comparison to other acid catalysts chosen 
for comparison. This result was explained by the authors considering the low acidity of HNTs, which avoided the isomerization of the synthetized products.

The modification of HNTs with 1,1'-(6-(propyl amino)-1,3,5-triazine-2,4-diyl)bis(pyridinium) hydrogen sulfate [(PATDBP $\left.)\left(\mathrm{HSO}_{4}\right)_{2} @ \mathrm{HNT}\right]$ was crucial to obtain a recoverable and reusable catalyst for the synthesis of naphthopyranopyrimidine derivatives via a three-component reaction under solvent-free conditions [60]. Catalytic tests highlighted the importance of HNTs as support for this kind of reactions; indeed, compared to other commonly used Lewis and Brønsted acids, the catalytic active species linked onto the HNTs showed superior activity in terms of catalyst loading, reaction time, yield, turn-over number and turn-over frequency.

Polyvinylpyrrolidone modified HNTs were used as support for the immobilization of metal-organic frameworks (MOFs) of $\mathrm{UiO}-66-\mathrm{SO}_{3} \mathrm{H}-\mathrm{X}$, where $\mathrm{X}$ stands for the amount of immobilized acidic MOFs (PVPHNTs@UiO-66- $\mathrm{SO}_{3} \mathrm{H}-\mathrm{X}$ ); in particular, the authors choose to investigate nanomaterials with $X=0.5,1,2$ and 3 [61]. The obtained nanomaterials where then used as catalysts in the fructose hydrolysis to hydroxymethylfurfural (HMF). Under optimal conditions, a high HMF yield up to $92.4 \%$ with fructose conversion was obtained with PVPHNTs@UiO-66- $\mathrm{SO}_{3} \mathrm{H}-2$ as a catalyst. The better catalytic activity of this system in comparison to the other prepared was attributed to its large specific surface area and effective acid sites.

Chloroperoxidase (CPO) was successfully immobilized on both HNTs' surfaces by exploiting both electrostatic and hydrogen bonding interactions [62]. To achieve this objective the authors adopted two different synthetic approaches: (i) they, in a first attempt, treated HNTs with $2 \mathrm{~mol} \mathrm{~L}^{-1} \mathrm{H}_{2} \mathrm{SO}_{4}$ for $48 \mathrm{~h}$, an experimental procedure often used to increase the lumen diameter which could be beneficial in the increase of the loading amount of enzyme; and (ii) the authors also firstly modified the HNTs surface with chitosan, and the obtained coated clay was used for the immobilization of $\mathrm{CPO}$ by the presence of favorable hydrogen bonding interactions between $\mathrm{CPO}$ and the functional groups onto chitosan. The immobilization of this enzyme on HNTs was important in the improvement of its thermal stability. The authors indeed found that, conversely to "free" CPO, which catalytic activity dropped rapidly with the increase of temperature (only $14.2 \%$ and $11.66 \%$ of activity is retained after $1 \mathrm{~h}$ incubation at $70{ }^{\circ} \mathrm{C}$ and $80^{\circ} \mathrm{C}$ respectively), the activity of immobilized $\mathrm{CPO}$ decreased more slowly. The nanomaterial HNTs/CPO retains ca. $87.63 \%$ activity at $80^{\circ} \mathrm{C}$, and no activity loss at $70^{\circ} \mathrm{C}$ at the same condition. Furthermore, the investigated nanomaterials demonstrated good catalytic performances in the degradation of isoproturon in wastewater.

Finally, recently, Agnihotri et al. reported a novel nanobiocatalyst by the combination of magnetic HNTs (MHNTs) and cellulase enzyme [63]. The obtained nanomaterial showed an excellent catalytic activity at elevated temperatures, hydrolyzation continuously over longer durations, ionic liquid-tolerant characteristics and eco-friendly attributes - features which made the cellulase-MHNTs amenable for high cellulose conversion.

\subsubsection{HNTs as Support for Metal Catalyst}

One of the major drawbacks of the use of metal nanoparticles for catalytic purposes is the fact that they tend to agglomerate during a catalytic process, resulting in a worsening of their performance. So, up to now, an important challenge is the development of catalytic systems which can stabilize metal nanoparticles of small dimensions, are stable and can be reused for several consecutive runs without loss of catalytic activity. In this context, clays, and in particular HNTs, represent versatile materials suitable for the aforementioned purposes.

One of the most studied reactions catalyzed by metal nanoparticles is the photodegradation of pollutants. Nowadays, environmental pollution, especially the water one, represents one of the most critical problems which have to be handled in the immediate future [64]. In this field, halloysite, because of its interesting features, has been proposed as support for the assembly of nanoarchitectures for pollutant photodegradation. 
Different studies dealing with the photodegradation of antibiotics or organic dyes from aqueous solution by means of valuable nanocatalysts based on metal nanoparticles supported on HNTs, both pristine and modified, have been reported (Table 3) [48,65-70].

Table 3. Metal nanoparticles supported on HNTs for application as photocatatalysts for pollutant removal.

\begin{tabular}{|c|c|c|c|}
\hline Metal NPs & Supporting Method & Pollutant & Ref. \\
\hline $\mathrm{TiO}_{2}$ & impregnation & rhodamine B & [68] \\
\hline $\mathrm{CdS}$ & hydrothermal & tetracycline & {$[66]$} \\
\hline $\mathrm{ZnO}$ & calcination & tetracycline & [67] \\
\hline AgNPs & electrostatic immobilization & methylene blue & [48] \\
\hline $\mathrm{CeO}_{2} / \mathrm{AgBr}$ & microwave & methyl orange & [65] \\
\hline $\mathrm{Au}-\mathrm{Ni} / \mathrm{Fe}_{3} \mathrm{O}_{4}$ & impregnation & Congo Red & [69] \\
\hline $\mathrm{TiO}_{2}$ & impregnation & methylene blue & [71-73] \\
\hline $\mathrm{ZnO}$ or $\mathrm{TiO}_{2}$ & deposition & methylene blue & [74] \\
\hline $\mathrm{LaFeO}_{3}$ & sol-gel & chlortetracycline & [75] \\
\hline $\mathrm{TiO}_{2}$ and $\mathrm{Fe}_{2} \mathrm{O}_{3}$ & hydrothermal and sol-gel & $\begin{array}{l}\text { 2-chloro-, 2,6-dichloroaniline and } \\
\text { aniline }\end{array}$ & [76] \\
\hline $\mathrm{W}_{18} \mathrm{O}_{49}$ & $\begin{array}{c}\text { hydrothermal process coupled with a calcination } \\
\text { treatment }\end{array}$ & methyl orange & [77] \\
\hline $\mathrm{Fe}_{3} \mathrm{O}_{4}$ & polydopamine assisted deposition & methylene blue & [78] \\
\hline
\end{tabular}

Recently, to improve the photocatalytic properties of $\mathrm{TiO}_{2} \mathrm{NPs}$, Lee et al. synthetized a $\mathrm{La}^{3+}$ doped $\mathrm{TiO}_{2}$ on $\mathrm{HNTs}\left(\mathrm{La} / \mathrm{TiO}_{2} @ \mathrm{HNTs}\right)$ catalyst by a two steps procedure based on a sol-gel process followed by a sonochemical method [79]. First, the authors synthetized $\mathrm{TiO}_{2}$ NPs by a low-temperature sol-gel process using titanium(IV) isopropoxide precursor supported on the HNTs surface. Then, the immobilized $\mathrm{TiO}_{2} \mathrm{NPs}$ were doped with lanthanum nitrate hexahydrate precursor in a sonochemical method (Figure 5).

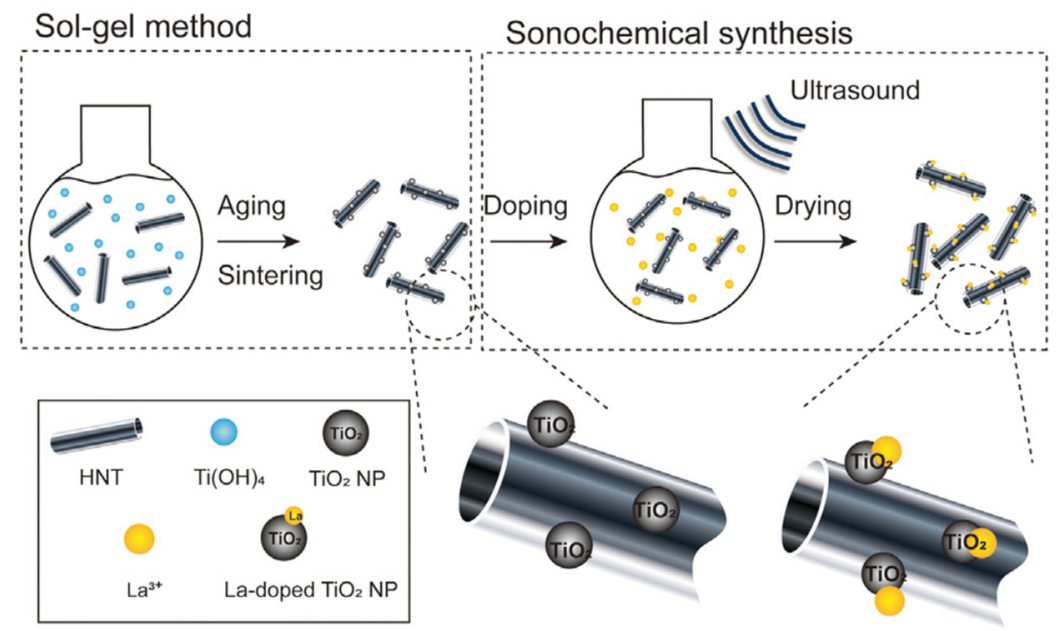

Figure 5. Synthesis of $\mathrm{La} / \mathrm{TiO}_{2} @ \mathrm{HNTs}$ nanomaterial. Reproduced with permission from ref. [79]. Copyright 2021 Elsevier.

The authors found that the combination of HNTs and lanthanum doping on $\mathrm{TiO}_{2}$ led to synergistic photolysis activity enhancement, increasing the catalytic activity by ca. 3 times in comparison to undoped $\mathrm{TiO}_{2}$. The use of HNTs as support also offered an easy separation method using centrifugation. Furthermore, the doped $\mathrm{TiO}_{2} \mathrm{NPs}$ supported onto HNTs showed an improved photolysis activity under the sole sunlight.

The selective modification of HNTs lumen with EDTA (HNTs-EDTA) allowed to immobilize into HNTs iron oxide $\left(\alpha-\mathrm{Fe}_{2} \mathrm{O}_{3}\right)$ by exploiting the strong affinity of EDTA for $\mathrm{Fe}^{3+}$ ions [80]. The immobilization of the organic moiety into the lumen was proven 
by solid-state NMR. In particular, the authors found that the typical NMR signal of the octahedral $\mathrm{AlO}_{6}$ of HNTs at ca. 6.8 ppm was upfielded after the binding of EDTA, and conversely no shift of the silicon NMR signal at -90.7 ppm was observed. Due to the selective modification of HNTs lumen, the authors developed an inorganic micelle-like architecture that helps the loading of $\mathrm{Fe}^{3+}$ ions and the subsequent formation of rod-shaped nanoscale $\mathrm{Fe}_{2} \mathrm{O}_{3}$. The presence of iron oxide inside the lumen due the decomposition of iron-EDTA complex was highlighted by XRD analysis, which exhibited the presence of some newly size of hematite. The nanomaterial so obtained was used as catalyst for the photodegradation of organic dyes under UV, vis and direct sunlight irradiation at room temperature. The nanomaterial showed enhanced photocatalytic activity, which could be due to the channelized electron transport in the 1D nanorods, and also to the low possibility of electron-hole recombination [81].

Similarly, the HNTs lumen was modified with Ag NPs through electrostatic interaction by the positively charged HNTs inner surface and the negatively charged N-acetyl-Lcysteine-modified Ag NPs [82]. The nanomaterial obtained was tested as catalyst in the reduction reaction of 4-nitrophenol showing good catalytic performance and reusability.

Recently, Yang et al. reported the immobilization of $\mathrm{Co}_{3} \mathrm{O}_{4}$ nanoparticles onto HNTs by a non-aqueous deposition-precipitation, followed by thermal treatment, and they used the obtained nanomaterial as catalyst for the reduction of 4-nitrophenol and organic dyes [83].

The use of HNTs support was useful in the obtaining of small $\mathrm{Co}_{3} \mathrm{O}_{4}$ nanoparticles, due to an effect of pristine HNTs on the growth of the cobalt precursor via adsorption-caused local concentration change of cobalt ions (Figure 6).
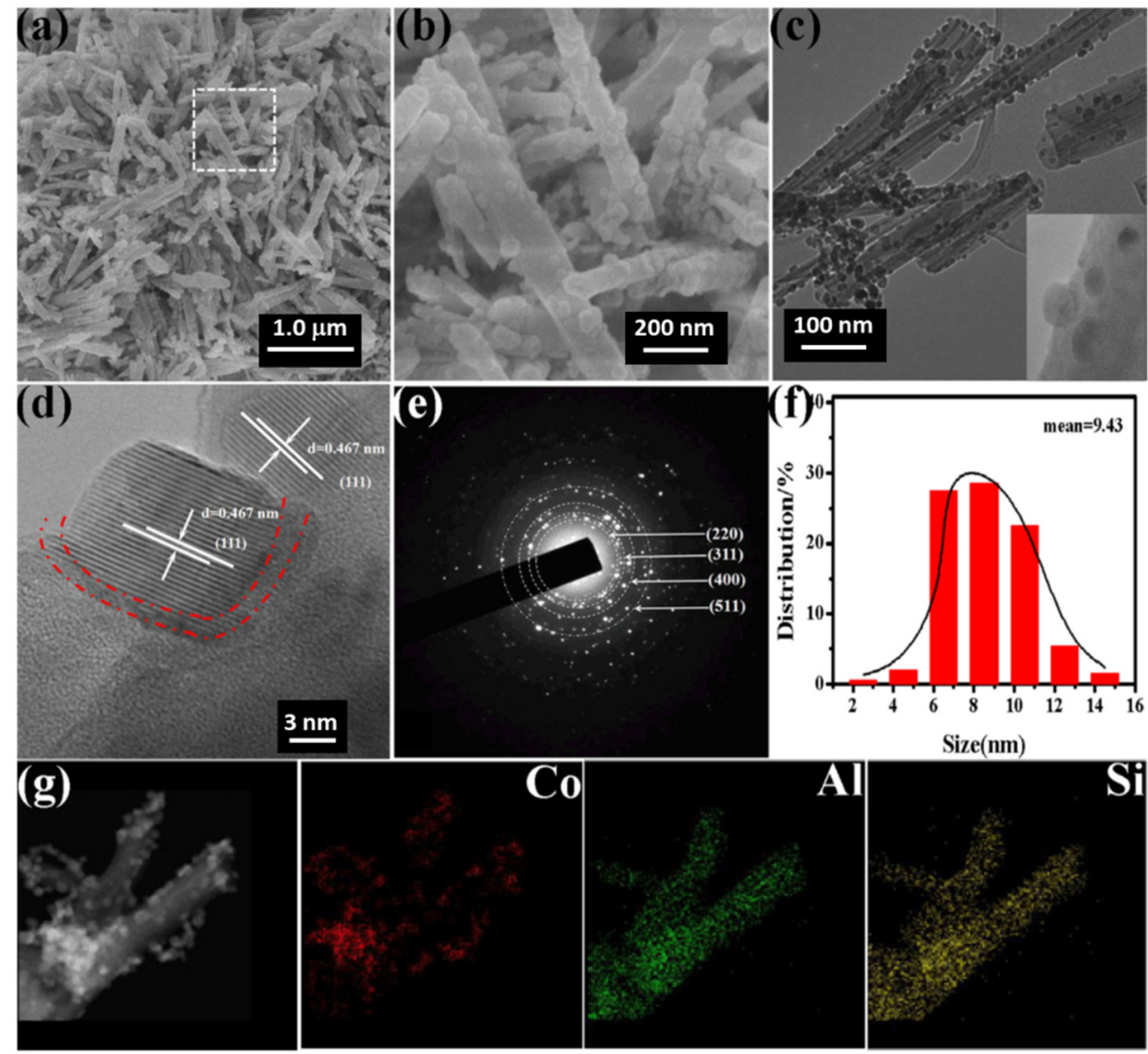

Figure 6. (a,b) FESEM images, (c) TEM images, (d) HRTEM image, (e) SAED pattern, (f) Particle size distribution and (g) EDX elemental mapping images of $\mathrm{Co}_{3} \mathrm{O}_{4} / \mathrm{HNTs}$ nanomaterial. Reproduced with permission from ref. [83]. Copyright 2021 Elsevier.

Catalytic studies showed that the $\mathrm{Co}_{3} \mathrm{O}_{4} / \mathrm{HNTs}$ nanomaterial displayed enhanced catalytic performances toward the reduction of aqueous organic contaminants, in terms of 
induction period, durability and conversion rate, in comparison to the unsupported $\mathrm{Co}_{3} \mathrm{O}_{4}$ NPs. The authors explained these results considering the fact that halloysite nanotubes endowed $\mathrm{Co}_{3} \mathrm{O}_{4}$ nanoparticles with the specific structural characteristics and the cooperative effects confirming, once again, the importance of using HNTs in the catalytic field.

A one-pot synthesis of small ZnO NPs onto HNTs external surface was achieved by the immobilization of the commercial bulk $\mathrm{ZnO}$ onto pristine HNTs in a phosphate buffer $\mathrm{pH} 8.0$ [84]. Briefly, in alkaline conditions there were obtained $\mathrm{Zn}^{2+}$ ions that successively interact with the hydroxyl group present on the HNTs external surface, establishing an $\mathrm{O}-\mathrm{Zn}^{2+}$ coordination bond between the clay and Zn. S/TEM images confirm the presence of evenly distributed nanoparticles onto HNTs surface with an average mean size of $2.4 \mathrm{~nm}$. The obtained nanomaterial was successfully tested as photocatalyst for organic dyes degradation.

To reduce the toxicity to cadmium-based nanomaterials, Lvov and Stavitskaya et al. immobilized CdS quantum dots (QDs) on HNTs, developing a nanomaterial which showed good biosafety in vitro, and indeed their results demonstrated that more than $80 \%$ of eukaryotic cells were viable after incubation with cadmium and mixed sulfides stabilized by HNTs [85]. Vinokurov et al. [86] immobilized CdS NPs both in the lumen via the Schiff base assisted technique, and on the outer surface of halloysite for application as catalyst for the photocatalytic hydrogen production from aqueous solutions of $\mathrm{Na}_{2} \mathrm{~S} / \mathrm{Na}_{2} \mathrm{SO}_{3}$ under the influence of visible light upon irradiation at $\lambda=450 \mathrm{~nm}$. The experimental results showed that the HNTs based core-shell CdS photocatalyst possesses enhanced catalytic activity and high stability in the release of hydrogen under the action of visible light radiation. Furthermore, the obtained photocatalyst can be recycled for at least five consecutive cycles without loss of its photocatalytic activity.

Starting from these findings the same authors in another work, doped the CdS NPs stabilized onto and into HNTs with Ru NPs to obtain a photocatalyst for hydrogen evolution [87]. To efficiently bind cadmium nitrate onto HNTs, the clay was first functionalized with azine as a chelating agent, and then the complex was treated with thioacetamide to finally achieve the CdS NPs supported onto HNTs (CdS/Halloysite). Afterwards, this nanomaterial was used for Ru deposition (Figure 7).

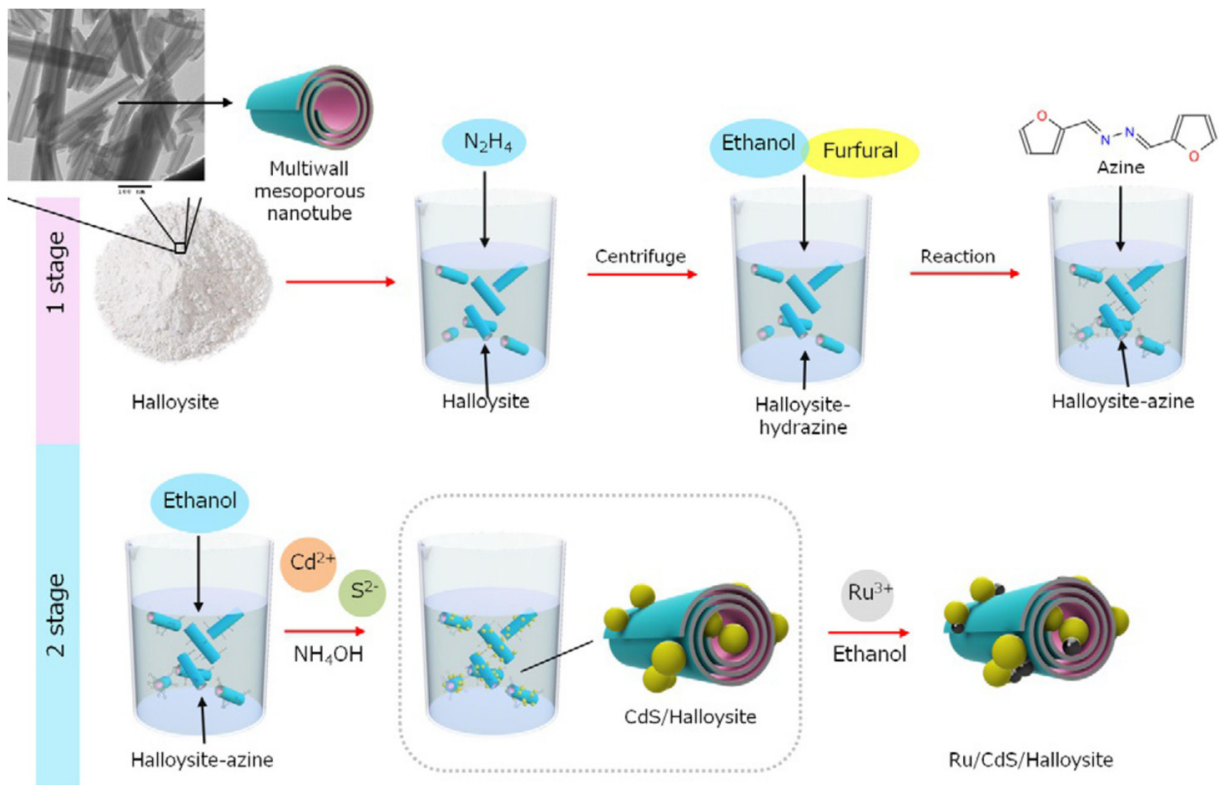

Figure 7. General procedure for preparation of $\mathrm{Ru} / \mathrm{CdS} /$ halloysite photocatalysts. Reproduced with permission from ref. [87]. Copyright 2020 John Wiley and Sons.

Besides the reduction reactions, from an environmental point of view, great importance is covered by the oxidation of volatile organic compounds (VOC), which represents a danger 
for the tropospheric atmosphere and human health. In this context, Liu et al. reported the synthesis and characterization of manganese oxides supported on halloysite, starting from different Mn precursors for thermal catalytic oxidation of formaldehyde [88]. The manganese oxide supported onto HNTs obtained by permanganate precursor exhibited the best catalytic activity leading to $90 \%$ of $\mathrm{CO}_{2}$ generation at $149{ }^{\circ} \mathrm{C}$.

Co NPs were also immobilized onto HNTs by several approaches to develop an efficient and low-cost catalyst for hydrogen production from sodium borohydride [89]. The authors synthetized three different halloysite-cobalt nanomaterials using the wetimpregnation and ligand assisted (based on silane or azines) methods. The characterization of the catalysts highlighted that the better method was the ligand-assisted one using azines, which both enhanced the metal loading and allowed to obtain small Co nanoparticles uniformly dispersed on the HNTs support. The presence of azine indeed increased the cobalt salt adsorption onto/into HNTs from 8 to $16 \mathrm{wt} \%$, and allowed making catalytic systems highly active in sodium borohydride hydrolysis. After optimization of the experimental conditions $\left(10 \mathrm{wt} \% \mathrm{NaBH}_{4}\right.$ and $2 \mathrm{wt} \% \mathrm{NaOH}$ at $\left.25^{\circ} \mathrm{C}\right)$, the authors tested the catalytic activity of the HNTs-based catalysts $\left(\mathrm{R}, \mathrm{L}\left(\mathrm{H}_{2}\right) / \mathrm{min} \times \mathrm{g}(\mathrm{cat})\right)$. An extraordinary catalytic activity $(3 \mathrm{~L} / \mathrm{min} \times \mathrm{g}(\mathrm{cat}))$ was obtained with ketazine as a complexation agent.

In the last few years, the use of $\mathrm{CeO}_{2}-\mathrm{ZrO}_{2}$ (CZ)-based three-way catalyst (TWC) has gained interest to control automobile exhaust emissions; however, the poor thermal stability of pure $\mathrm{CZ}$ has limited its application. One way to enhance the properties of $\mathrm{CZ}$ is its doping with $\mathrm{Al}_{2} \mathrm{O}_{3}$ obtaining the $\mathrm{CZA}$ catalyst. The synthesis of a hybrid system based on CZA and HNTs has been proven to be advantageous in terms of morphology, redox and textural property, and TWC performances of the obtained composites [90]. The presence of HNTs indeed produce an ink-bottle-type structure that can enhance the diffusion of both heat and gas towards or away from the active sites, and consequently exerts a positive influence on the catalytic activity. Furthermore, the HNTs dispersed in CZA due to the accelerated adsorption and diffusion of oxygen ions.

Similarly, $\mathrm{CeO}_{2}-\mathrm{WO}_{3}$ were immobilized onto HNTs by a molten salt treatment followed by the impregnation method for selective catalytic reduction of $\mathrm{NO}_{x}$ with $\mathrm{NH}_{3}$ in the presence of $\mathrm{SO}_{2}$ [91]. To improve the catalytic performance, the developed material was further modified with $\mathrm{Fe}_{2} \mathrm{O}_{3}$. Catalytic tests showed that the obtained catalyst possessed enhanced catalytic activity, high $\mathrm{N}_{2}$ selectivity over a wide temperature range and high sulfur-poisoning resistance. In particular, the presence of $\mathrm{Fe}_{2} \mathrm{O}_{3}$ onto the catalyst can increase the ratio of $\mathrm{Ce}^{3+}$, and the amount of surface oxygen vacancies and enhanced the interaction between active components.

$\mathrm{CeO}_{2}$ NPs were successfully immobilized onto pristine HNTs to develop a novel catalyst for the selective catalytic reduction of $\mathrm{NO}_{x}$ with ammonia $\left(\mathrm{NH}_{3}-\mathrm{SCR}\right)$ [92]. Due to the hydroxyl-rich octahedral sheet $(\mathrm{Al}-\mathrm{OH})$ groups in the HNTs lumen and the defect-rich nanoceria, the catalyst $\mathrm{CeO}_{2} / \mathrm{HNTs}$ obtained possessed more active oxygen species, oxygen vacancies and Brønsted acidity in comparison to the pure $\mathrm{CeO}_{2}$. These features favored the formation of $\mathrm{Ce}^{3+}$, strengthen the reduction of ceria and promote the $\mathrm{NH}_{3}$ adsorption capacity of the catalyst. Furthermore, the catalyst inhibited the $\mathrm{NH}_{3}$ over-oxidation via a reversible occupation/release cycle of the oxygen vacancies $\left(\mathrm{v}_{\mathrm{o}}\right)$ and hydroxyls $(-\mathrm{OH})$, resulting in an excellent $\mathrm{NO}_{x}$ removal efficiency of $>95 \%$ and $\mathrm{N}_{2}$ selectivity $>98 \%$ over a wide operating temperature window of $275-400{ }^{\circ} \mathrm{C}$ under a high space velocity of $177,000 \mathrm{~h}^{-1}$

Recently, Rahman et al. reported for the first time the stabilization of copper nanoparticles onto HNTs support by their seeding in mild conditions [93]. To achieve this purpose, glutathione was considered as both a reducing and a stabilizing agent for the synthesis of $\mathrm{Cu}$ nanoparticles, obtaining two different nanocatalysts called CuNCs@HNT and CuNCs@HNT-PS, respectively, depending on the synthetic pathway considered (one pot synthesis for the first one, post-synthesis for the latter).

Cobalt-chromium oxide were successfully immobilized onto HNTs $\left(\mathrm{CoCr}_{2} \mathrm{O}_{4}-\mathrm{HNTs}\right)$ by Bania et al. to be used as catalyst in the formation of $\beta$-aryl enals, enones and the aryl 
amines [94]. The authors of this work studied two different reactions catalyzed by the $\mathrm{CoCr}_{2} \mathrm{O}_{4}$-HNTs catalyst; the first one is a temperature-controlled reaction and the second is the photo-assisted one. In particular, the synthesis of $\beta$-aryl enals, enones from in situ oxidation of ethanol and isopropanol respectively, selective reduction of benzaldehydes and amination of aryl halides with DMF were studied under the thermal condition. Conversely, the oxidation of benzyl alcohols and light-driven synthesis of $\beta$-aryl enals and enones were carried out under the photo-assisted conditions. The results showed that the synthetized catalyst was highly active in the selective reduction of benzaldehydes without the use of any toxic reducing agents, and it was an efficient photocatalyst for highly selective photochemical oxidation of various benzyl alcohols.

Covalent modified HNTs with chlorine atoms (HNTs-Cl) were used as scaffolds for the dendrimers synthesis, which can efficiently immobilized Ce(IV) ions for catalytic purposes (Figure 8) [95]. The obtained nanomaterial was employed as a catalyst in the synthesis of a series of pyrido[3,2-c]coumarins via a one-pot, single step, three-component reaction of 4-aminocoumarin, aldehydes and aryl ketones. The authors of this work found that by using the HNTs based catalyst, it was possible to achieve an efficient and regioselective synthesis of pyrido[3,2-c]coumarins from terminal and internal alkynes.

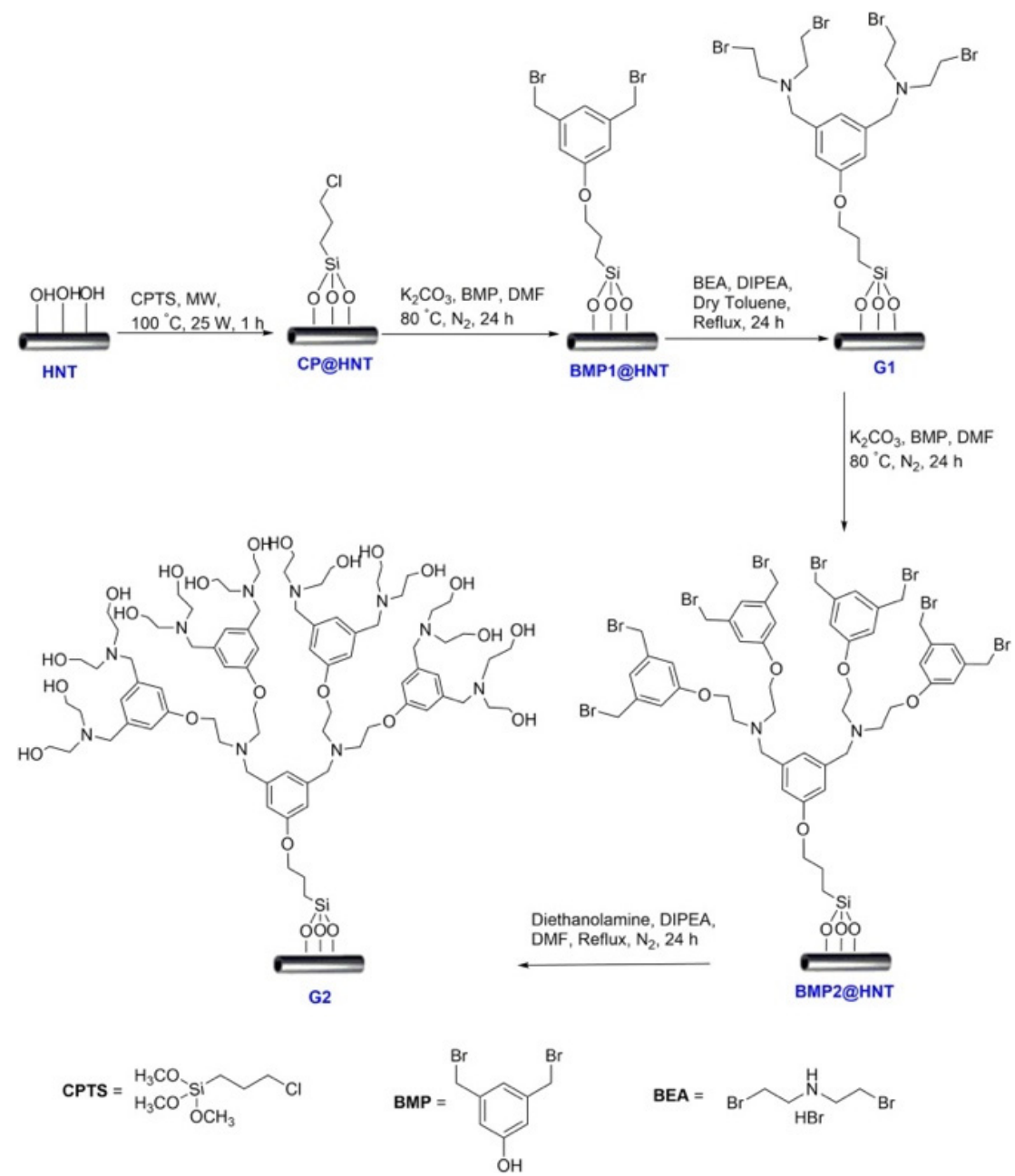

Figure 8. Schematic representation of the dendrimers supported onto HNTs. Reproduced with permission from ref. [95]. Copyright 2020 John Wiley and Sons.

Ruthenium nanoparticles of small dimensions and mainly localized inside the HNTs lumen were prepared by Vinokurov et al., and the obtained nanocatalyst was used for hydrogenation of phenol in aqueous media [96]. To achieve this objective, the authors first impregnated HNTs with aldehyde and amine compounds to form Schiff bases, inside which 
can capture $\mathrm{Ru}^{3+}$ ions from solution. After reduction of these ions with $\mathrm{NaBH}_{4}$, the authors obtained Ru NPs of ca. $1 \mathrm{~nm}$ in size, depending to the amount of Schiff bases present into HNTs. The catalytic activity of the synthetized nanocatalysts was evaluated in terms of surface turnover frequency (TOFs). The best results obtained showed a phenol conversion of $100 \%$ (main product obtained cyclohexanol) with a catalyst loading of $15 \mathrm{mg} / 300 \mathrm{mg}$ of phenol and of ca. $60-70 \%$, by decreasing three times the catalyst loading with a TOFs value of $8210 \mathrm{~h}^{-1}$.

A step-forward to the use of HNTs as support for Ru NPs was made some years later by the same authors, who proposed the development of catalytic core-shell nanoreactors based on hydrophobized HNTs to stabilize the metal NPs [97]. To achieve this goal, they modified the external HNTs surface with three different alkyltriethoxysilanes, namely the ones with the tail length of $C_{3}, C_{8}$ and $C_{18}$. By adopting this strategy, a hydrophobic shell was created onto the HNTs outer surface to avoid the adsorption of $\mathrm{Ru}^{3+}$ ions onto the negatively charged HNTs external surface and forces them into the hydrophilic lumens (Figure 9). Contact angle measurements showed an increase in the $\theta$ value by increasing the alkyl length of the silane. Thanks to the hydrophobic shell, the Ru NPs were formed preferentially inside the tubes, resulting in the formation of stable, active and recyclable catalytic system. As for an example, the longer the silane alkyl chains shell $\left(\mathrm{C}_{18}\right)$, the more complete is the $\mathrm{Ru}$ loading ( $2.7 \mathrm{wt} \% \mathrm{Ru}$ vs. 3.0 theoretical value) in the final nanocatalyst. This was confirmed by TPR- $\mathrm{H}_{2}$ measurements and TEM images, which also allowed to esteem a mean size of 4.6-5.0 $\mathrm{nm}$ in diameter.

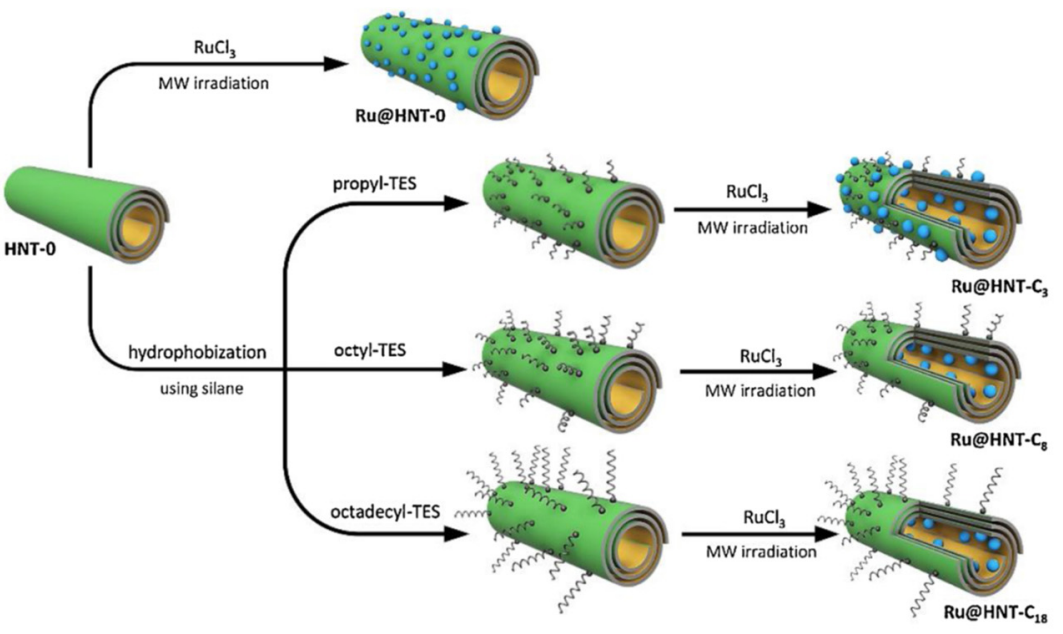

Figure 9. Scheme of the hydrophobization and ruthenium deposition. Reproduced with permission from ref. [97]. Copyright 2021 Elsevier.

The nanomaterial was tested as catalyst in aromatics hydrogenation both in biphasic medium (50 vol\% in) water and organic one. The experimental results showed that the $\mathrm{Ru}$ NPs supported onto octadecyltriethoxysilane-modified HNTs was the most promising catalyst in benzene hydrogenation, in both a biphasic system with water (TOF $=4371 \mathrm{~h}^{-1}$ ), and organic medium $\left(\mathrm{TOF}=8090 \mathrm{~h}^{-1}\right.$ ), showing excellent conversions and selectivity to cyclohexane of $100 \%$.

Acid-treated HNTs were successfully used as support for the immobilization of Ni and Mo nanoparticles to be used as catalysts in the n-decane hydroconversion reaction [98]. Trying to improve the catalytic performance, the authors, beside the single nanoparticles, also used HNTs to support a combination of the metals (Ni-Mo). Metallic Ni-Mo nanoparticles supported on acid-treated HNTs showed the best catalytic performance. This result was explained in the light of a promoting effect exerted by nickel, which facilitates the reduction reaction and allows the synthesis of smaller metal nanoparticles.

$\mathrm{CuFe}_{2} \mathrm{O}_{4}$ nanoparticles were immobilized onto HNTs' surface, and used as a catalyst for one-pot multicomponent reaction to synthetize pyrazolopyridine derivatives [99]. The 
HNT-based materials showed high catalytic activity, avoiding the agglomeration of the metal nanoparticles. To explain the catalytic behavior of the nanomaterial, the authors proposed a Hantzsch-type mechanism. The $\mathrm{CuFe}_{2} \mathrm{O}_{4} @ \mathrm{HNTs}$ catalyst acted as a Lewis acid, and played an important role during the course of the reaction, accelerating the multicomponent process (Figure 10).



Figure 10. Proposed mechanism for the synthesis of pyrazolopyridine derivatives in the presence of $\mathrm{CuFe}_{2} \mathrm{O}_{4} @ \mathrm{HNTs}$. Reproduced with permission from ref. [99].

Similarly, electrostatic interactions between the negatively charged HNTs surface and silver cations were exploited as a starting point for the synthesis of core-shell structured halloysite-based photocatalyst [100]. In a subsequent step, the nucleation and growth of $\mathrm{Ag}_{3} \mathrm{PO}_{4}$ led to the formation of $\mathrm{Ag}_{3} \mathrm{PO}_{4} @ \mathrm{HNTs}$ nanomaterial (Figure 11), which showed superior photocatalytic performance towards the degradation of rhodamine $\mathrm{B}$. The excellent photocatalytic activity of the $\mathrm{Ag}_{3} \mathrm{PO}_{4} @ \mathrm{HNTs}$ was explained by a combination of both HNTs and $\mathrm{Ag}_{3} \mathrm{PO}_{4}$ properties; in particular, the presence of HNTs ensures rapid dye adsorption onto the catalyst surface, and reduces $\mathrm{Ag}_{3} \mathrm{PO}_{4}$ band gap and the recombination rate. The latter was supposed to be due to a decreased interface defect density, in combination with a field-effect passivation induced by a negative fixed charge in the HNTs shells.

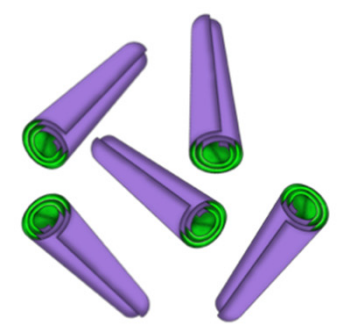

HNTs
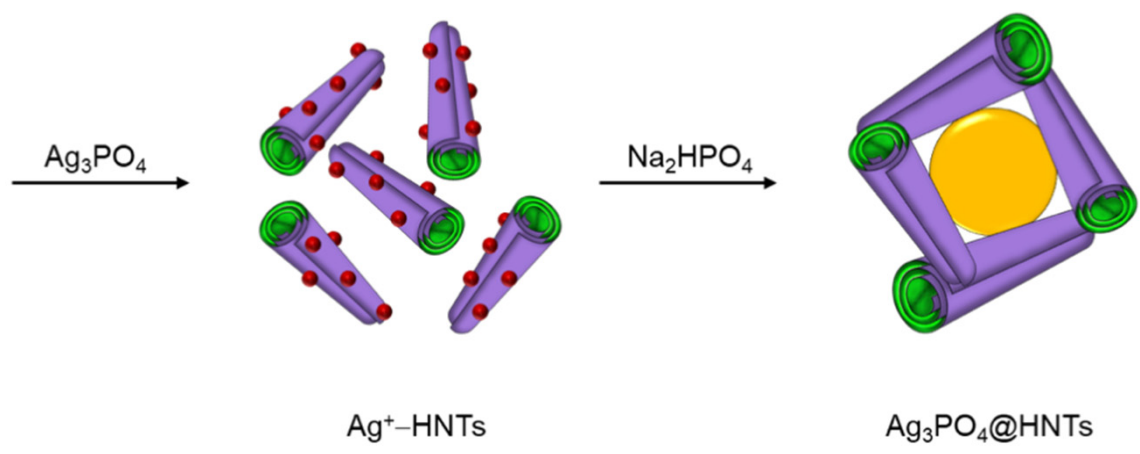

$\mathrm{Ag}_{3} \mathrm{PO}_{4} @ \mathrm{HNTs}$

Figure 11. Schematic representation of the synthesis of core-shell structured $\mathrm{Ag}_{3} \mathrm{PO}_{4} @ \mathrm{HNTs}$ nanomaterial. Adapted with permission from ref. [100]. Copyright 2017 Elsevier. 
Gold nanoparticles were successfully stabilized on HNTs [101] affording Au/HNTs nanomaterial, which demonstrated to possess high catalytic activity in the solvent-free aerobic oxidation of benzyl alcohol [102].

In 2017, Pakkanen et al. reported a new method for the synthesis of gold nanoparticles (AuNPs) supported on pristine halloysite nanotubes as a catalyst [103]. The authors exploited electrostatic interaction between the negatively charged HNTs external surface and the positively-charged AuNPs. Firstly, to ensure AuNPs stabilization and control the size and surface functionality, gold nanoparticles were obtained in the presence of polyethyleneimine (PEI) used as a capping agent and a stabilizer. By this approach, it was possible to control the gold content on HNTs' surface.

The catalytic properties of the synthetized material were studied in the oxidation reaction of benzyl alcohol in the presence of hydroxide ions.

Similarly, starting from thiol-modified HNTs, gold nanoparticles of small dimensions (ca. $2.4 \mathrm{~nm}$ ) were immobilized onto HNTs' external surface (HNTs@Au) [104]. The synthetized nanomaterial was successfully tested as catalyst in the reduction reaction of 4-NP. The catalytic performances of HNT@Au were outstanding, reaching remarkable TOF values (up to 2,204,530 $\mathrm{h}^{-1}$ ). Finally, in this work the authors also exploited a flow approach which preserves the physical integrity of the catalyst, and also allows for its easy recovery and recycling (Figure 12). Conversely to a stationary system with stirring, the developed flow system ensured the prolonged use of the catalyst, showing good productivity with a reduction of waste production.

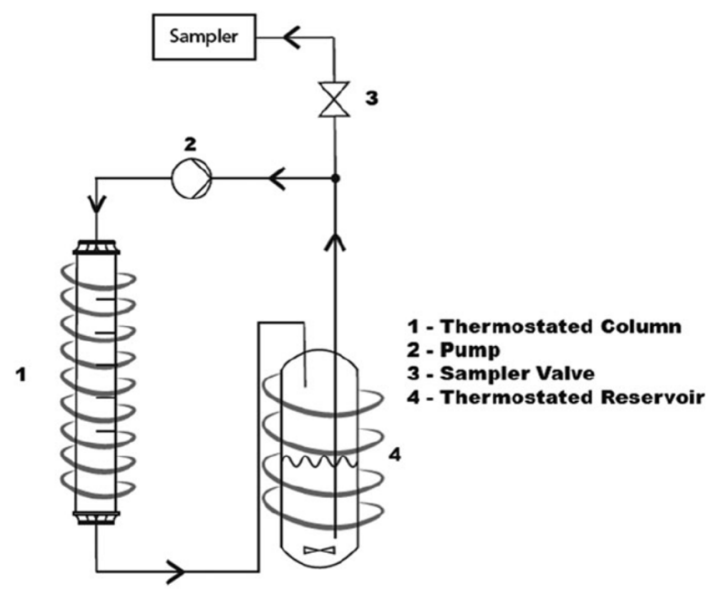

Figure 12. Schematic representation of the flow reactor based on HNTs developed for 4-NP reduction. Reproduced with permission from ref. [84]. Copyright 2018 John Wiley and Sons.

Trying to improve the metal nanoparticles loading onto the HNTs support, Carraro and Huang et al. recently etched HNTs by piranha solution to enhance the number of active sites on their surface [105].

Afterwards, the authors modified the etched-tubes with APTES, and on the obtained nanomaterials immobilized Au NPs (Pir-HNTs- $\mathrm{NH}_{2}-\mathrm{Au}$ ). The obtained material was also used as a catalyst for 4-nitrophenol reduction. The obtained results showed that the $\mathrm{Au}$ NPs immobilized onto etched nanomaterials possessed superior catalytic activity than those immobilized on APTES-modified HNTs, with an apparent reaction rate constant for Pir-HNTs-NH $\mathrm{N}_{2}-\mathrm{Au}$ of $1.3 \times 10^{-2} \mathrm{~s}^{-1}$, which is ca. $53 \%$ higher than that of $\mathrm{HNTs}-\mathrm{NH}_{2}-\mathrm{Au}$ $\left(8.5 \times 10^{-3} \mathrm{~s}^{-1}\right)$.

Magnetic nanoparticles of small dimensions were synthetized on pristine HNTs surface by Tsoufis et al. [106]. They envisaged a novel approach based on the modification of wet-impregnation method to obtain a nanomaterial with catalytic properties (HNTsmagnetite). The performances of the systems were studied in the catalytic decomposition of pentachlorophenol from reaction solutions at room temperature. The HNTs-magnetite nanomaterial showed much higher catalytic efficiency and kinetics, compared to free un- 
supported magnetite NPs synthesized by alternative synthetic routes (e.g., co-precipitation method). Furthermore, the use of HNTs allowed easily recycle of the catalyst and its efficient re-use for several consecutive runs without any loss of its catalytic activity.

In the following years, different approaches for palladium nanoparticles immobilization on HNTs supports were developed.

Heravi et al. [107] achieved the stabilization of Pd nanoparticles onto HNTs, by the modification of the clay with a Schiff base ligand obtaining a heterogeneous catalyst, which was successfully employed in the Sonogashira reaction in an aqueous medium.

Similarly, the immobilization of Pd NPs on cyclodextrin covalently grafted onto HNTs (HNTs-CD@Pd) was reported and used as catalyst in the Sonogashira and Heck reactions [108]. The catalyst was obtained by reacting tosylated CD with thiosemicarbazide modified HNTs (Scheme 1), and on which were subsequently immobilized Pd NPs. The catalyst was successfully tested in the C-C cross coupling reactions of Heck and Sonogashira, showing good performances and recyclability up to five cycles with negligible Pd leaching.
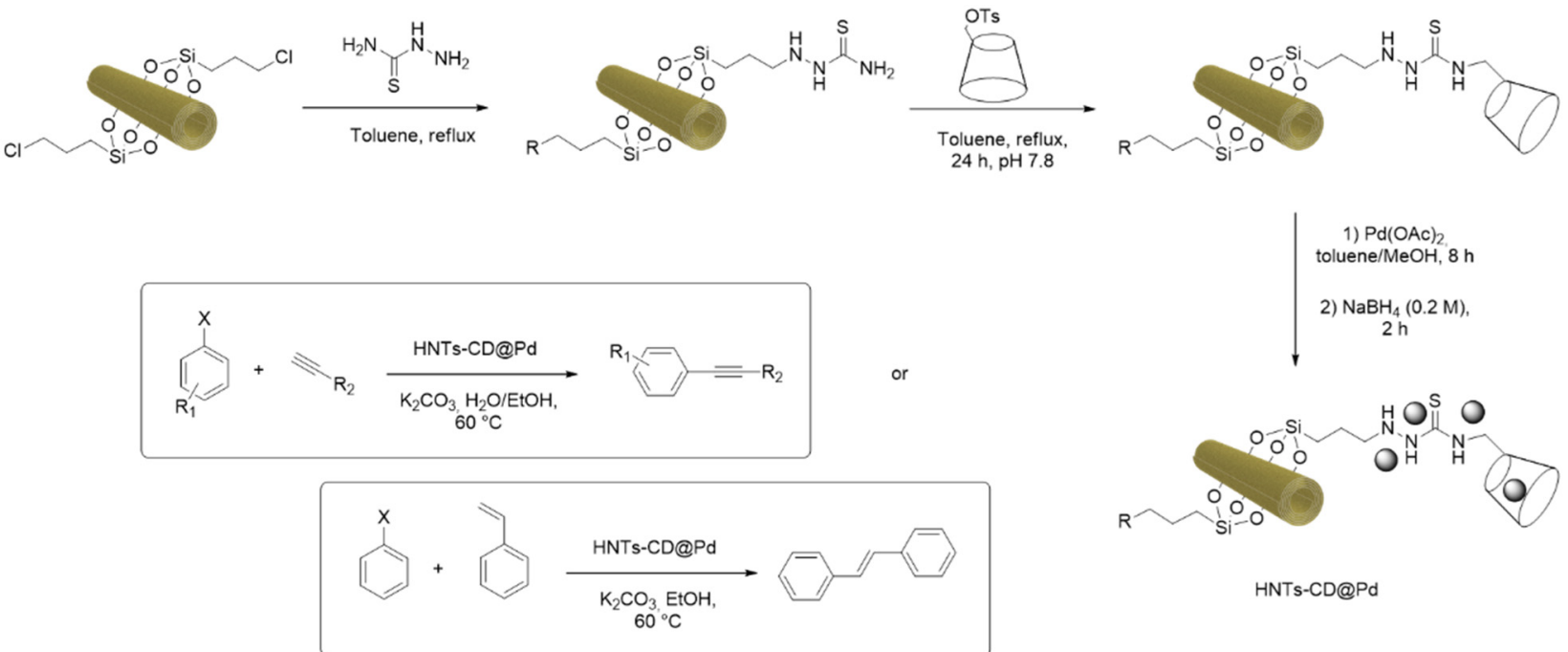

Scheme 1. Synthesis of the HNTs-CD@Pd catalyst and its application in the Sonogashira and Heck reaction.

Ionic liquids were successfully grafted into HNTs lumen by Dedzo et al. [109]. Successively, the ionic liquids moieties were used to immobilize Pd NPs affording a nanocatlyst which showed high activity in in the reduction reaction of 4-nitrophenol to 4-aminophenol.

Pd immobilization via Schiff base was also achieved by Hey et al., who explored the effect of different amines:aldehyde ratio for the modification of HNTs' external surface to obtain an innovative three-way core shell catalyst [110]. To do this, the authors mixed HNTs with different ratios of o-phenylenediamine or ethylenediamine and salicylaldehyde, and the nanomaterial obtained was reacted with $\mathrm{Pd}\left(\mathrm{NO}_{3}\right)_{2}$ to finally obtain the Pd@HNTs-Schiff base catalyst. By means of homogeneous precipitation, the catalyst was further used as support for $\mathrm{CeO}_{2}$. The experimental results highlighted an increased catalytic activity of the Pd@HNT-Schiff base, in comparison to Pd NPs supported on pristine HNTs. This result was explained by the synergistic effects exerted both of the $-\mathrm{C}=\mathrm{N}$ groups and HNTs. The first increases the metal-support interaction, while the second ones prevent metal aggregation acting as sintering barriers. Moreover, among the different amines used, ethylenediamine produced more $-\mathrm{C}=\mathrm{N}$ groups, which were helpful in the subsequent steps. Finally, by adding $\mathrm{CeO}_{2}$ to the obtained system, there ensured more oxygen vacancies which promote $\mathrm{NO}$ reduction and $\mathrm{C}_{3} \mathrm{H}_{8}$ and $\mathrm{CO}$ oxidation at elevated temperatures.

Bimetallic Pd alloy supported onto HNTs was reported by Al-Quaradwi et al. as a catalyst for $\mathrm{CO}$ oxidation [111]. Three different metals were considered for the alloy formation, and the final material was obtained by simple reduction with $\mathrm{NaBH}_{4}$. Among 
the different catalysts, the PdNi@HNTs one showed the best catalytic performance, allowing to obtain a $\mathrm{T}_{100}$ of $128^{\circ} \mathrm{C}$. The different catalytic activity of the nanomaterials was explained considering the dispersion and homogeneous distribution of the metals onto HNTs, which is strictly correlated to the catalyst deactivation via Ostwald ripening.

One of the most-studied organic reactions catalyzed by Pd NPs is the Suzuki-Miyaura reaction. The palladium-catalyzed Suzuki-Miyaura cross-coupling reaction of aryl halides with arylboronic acids [112] is one of the most adopted process for the synthesis of symmetric and asymmetric biaryls, which find application in the synthesis of pharmaceuticals. Also in this context, halloysite-based catalysts resulted very promising.

Kim and Rhee et al. exploited the coating of HNTs external surface with polymers to attach palladium nanoparticles on poly(N-isopropylacrylamide)-halloysite nanocomposites, obtaining hydrogels which were successfully applied as catalyst in the Suzuki reaction [113].

HNTs were also used to synthetize the so-called supported ionic liquid phase (SILP), which served for the stabilization of Pd NPs. To achieve this goal, HNTs-SH nanomaterial was modified by a thiol-ene reaction with an imidazolium bromide derivative. The resulting nanomaterial was used as a support for Pd NPs affording HNTs-SILP@Pd catalyst. Afterwards, the authors tested the catalytic performances of the obtained nanomaterial in the Suzuki cross coupling reaction between phenylboronic acid and a series of aryl halide. The nanomaterial was also easily recycled for up to five cycles without any loss of its catalytic activity [114]. In 2018, the same authors, following a similar approach, developed a highly cross-linked imidazolium salt modified HNTs for stabilization of Pd NPs [115]. The nanomaterial was used as catalyst in the Heck and Suzuki reactions under a non-conventional method. The cross-linked imidazolium salt modified HNTs catalysts showed high catalytic performances as testified both by the high TONs (up to 194,000) and TOF values (up to $3,880,000 \mathrm{~h}^{-1}$ ) obtained and by the good recyclability of the system for at least ten cycles with negligible Pd leaching.

Another interesting catalytic system based on SILP supported onto HNTs was developed by the use of triazolium salts derivatives for the immobilization of Pd NPs [116]. Two different triazolium salts derivatives were envisaged to obtain first and second generation HNT-based catalysts. According to the different thermal stability of the triazolium salts, it was found that the second-generation catalyst was more active and stable compared to the first one, as testified by the high yields obtained in the Suzuki reaction, as well as the good recyclability (Figure 13).

Similarly, HNTs external surface modification with furfural led to the synthesis of Schiff base-based HNTs, which can successfully immobilize Pd ${ }^{2+}$ ions (Figure 14) [117]. This nanomaterial was tested as catalyst in the Sukuzi reaction, showing high activity and recyclability.

The modification of HNTs external surface with N-(2-aminoethyl)-3-aminopropyltrimethoxysilane led to the development of a scaffold for the construction of PAMAM-like dendrimers [118]. The obtained nanomaterial was firstly treated with $\mathrm{Pd}(\mathrm{OAc})_{2}$ in toluene, and successively with $\mathrm{NaBH}_{4}$ giving the Pd@HNTs-PAMAM-ISA catalyst. The catalytic performances were testes in the Heck and Sonogashira reactions in a mixture water/ethanol (1:1). The experimental results showed good catalytic activity and recyclability up to 10 cycles with negligible Pd leaching.

Recently, the chemical treatment of HNTs by means different agents (such as $\mathrm{H}_{2} \mathrm{SO}_{4}$, $\mathrm{NaOH}, \mathrm{CTAB}$ and SDS) allowed to depose onto HNTs, Pd NPs by a simple mild reduction procedure [119]. Following this method, Pd/HNTs-NaOH, Pd/HNTs- ${ }_{2} \mathrm{SO}_{4}, \mathrm{Pd} / \mathrm{HNTs}-$ SDS and Pd/HNTs-CTAB were obtained by the reduction, by means of ascorbic acid, of Pd precursor $\left(\mathrm{K}_{2} \mathrm{PdCl}_{4}\right)$ in an aqueous solution containing pretreated HNTs. The metal loadings were estimated using ICP-OES analysis, and were found to be 2.37, 2.27, 2.24 and $2.12 \mathrm{wt} \%$ for Pd/HNTs-NaOH, Pd/HNTs- $\mathrm{H}_{2} \mathrm{SO}_{4}, \mathrm{Pd} / \mathrm{HNTs}-\mathrm{SDS}$ and Pd/HNTs-CTAB, respectively. The nanomaterials so obtained were thoroughly characterized to assess the best treatment for the development of catalytic systems. Afterwards, the authors 
tested all catalysts in the methane combustion reaction. The obtained results showed that among the used catalysts, $\mathrm{Pd} / \mathrm{HNTs}-\mathrm{NaOH}$ showed small Pd size, high metal-support interaction and highly dispersed Pd on both surfaces. Furthermore, it exhibited the highest catalytic activity, and increased chemical stability towards methane combustion compared to other counterparts.

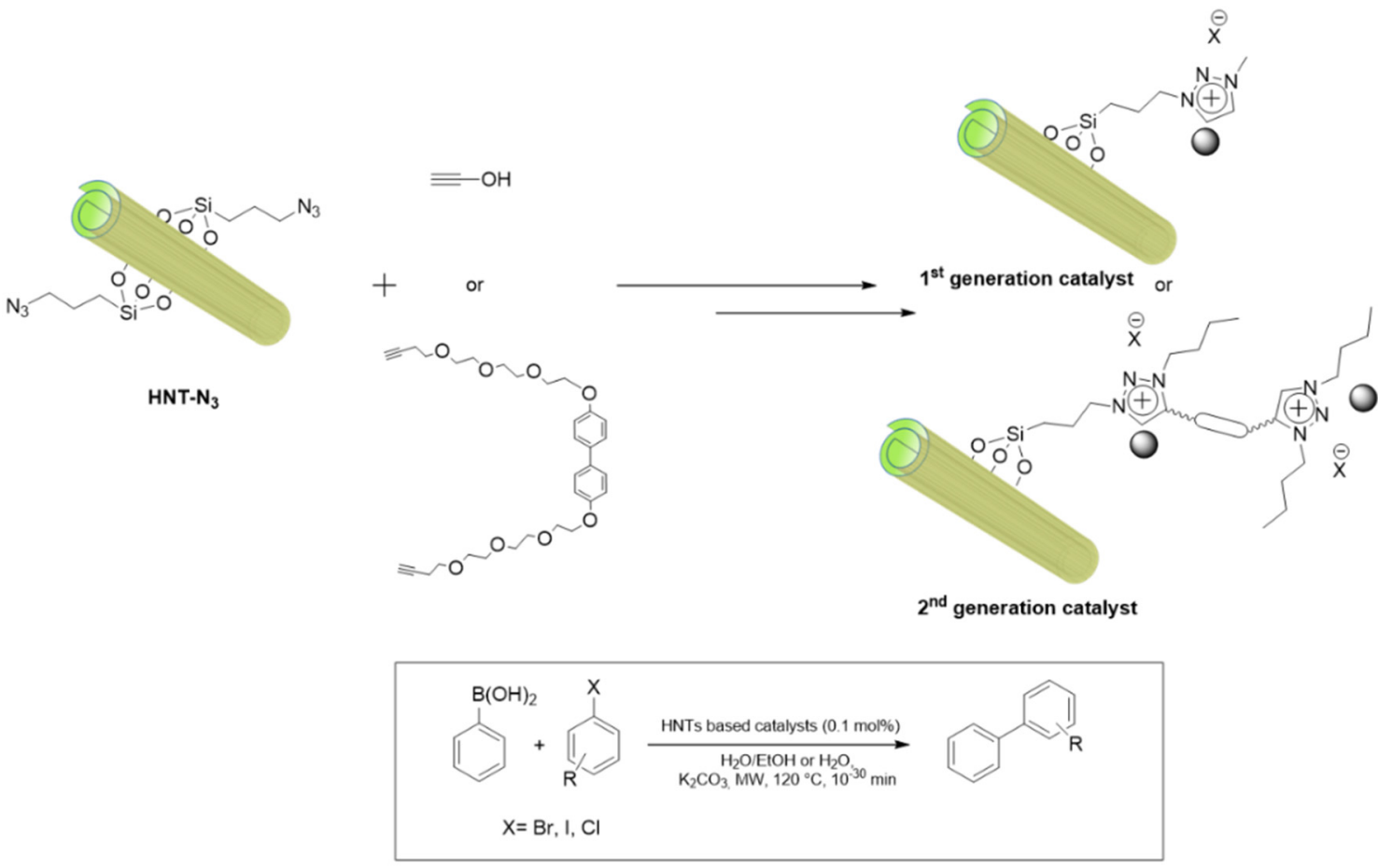

Figure 13. Synthesis of the 1st and 2nd generation HNTs triazolium salt-based catalysts and their application in the Suzuki reaction.

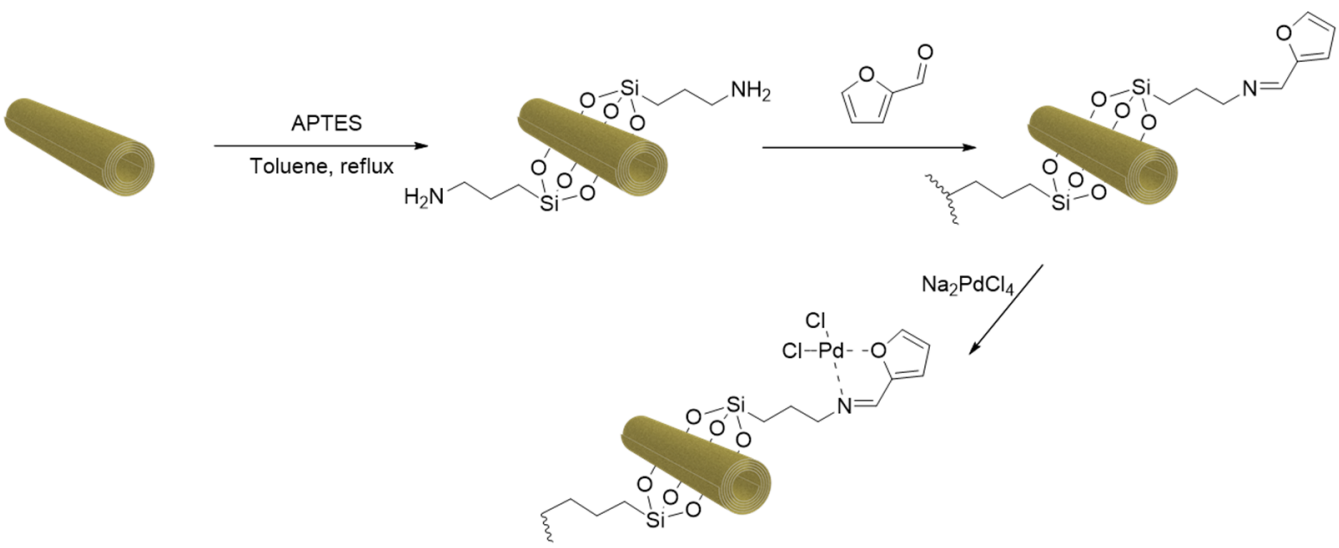

Figure 14. Schematic representation of the synthesis of Schiff base-based HNTs for immobilization of $\mathrm{Pd}^{2+}$ ions.

The hydrophobization of HNTs external surface by a two-step process based on a heating treatment of the clay, followed by its interaction with cetyltrimethylammonium bromide allowed to Xiao, Jiang et al. to force the synthesis of small Pd NPs inside HNTs lumen (Figure 15) [120]. The obtained catalyst showed the desired structure and favorable properties for methane combustion. In particular, it possessed evenly dispersed Pd NPs (ca. $2 \mathrm{~nm}$ ), better reducibility, a suitable ratio of $\mathrm{Pd}^{2+} / \mathrm{Pd}^{4+}$ and appropriate surface acidity, which allowed to obtain outstanding higher activity with the $\mathrm{T}_{99}$ decreasing from $620^{\circ} \mathrm{C}$ (unmodified catalysts) to $425^{\circ} \mathrm{C}$. 


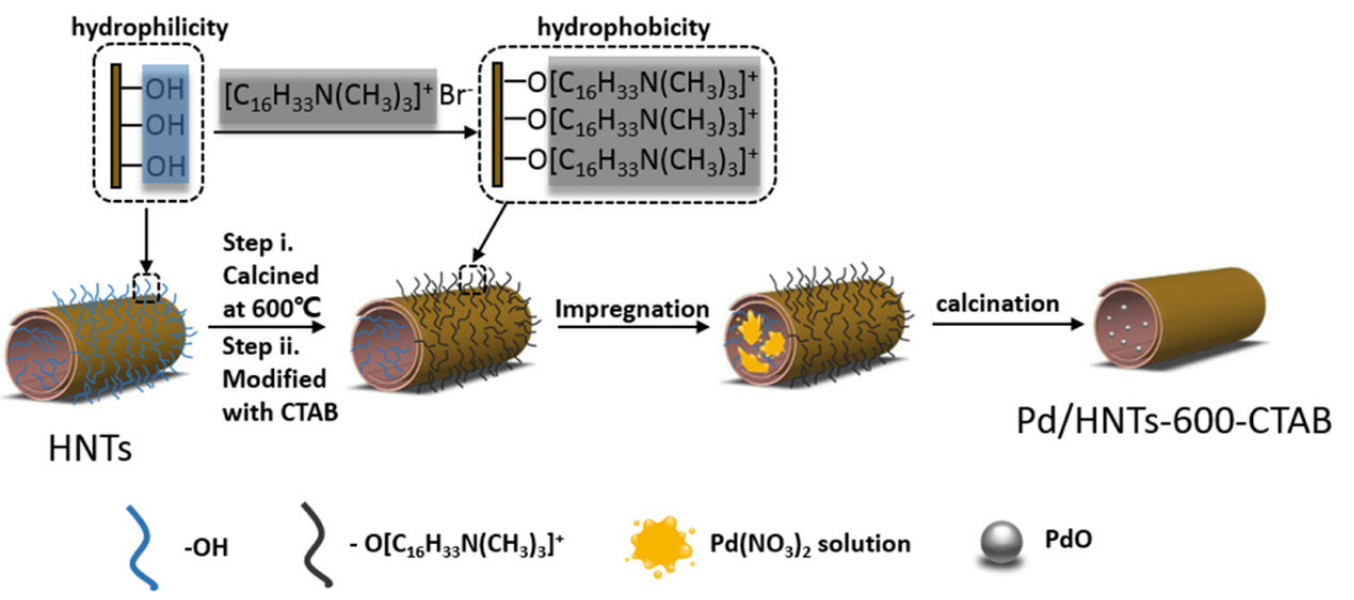

Figure 15. Schematic representation of the HNTs external surface hydrophobization to the selective loading of Pd inside the HNTs lumen. Reproduced with permission from ref. [120]. Copyright 2020 American Chemical Society.

\subsubsection{Halloysite for Biodiesel Production}

Climate change and the scarcity of fossil fuels pulled the scientific research to find alternative renewable energy resources. Biodiesel is considered as a promising alternative owing to the advantages of renewability, biodegradability, no-toxicity and low pollutant emission. In this context, HNTs have found application as catalysts in for biodiesel production. One of the first example, reported the use of raw HNTs as a heterogeneous catalyst in the methylic and ethylic esterification of lauric acid [121]. The obtained results showed that halloysite was as able to esterify lauric acid and produce fatty esters, as demonstrated by the higher reaction yields obtained in the presence of HNTs, in comparison to those achieved by thermal conversion.

Subsequently, raw HNTs were used in the esterification reaction between levulinic acid and methanol to afford methyl levulinate [122]. Different experimental conditions were considered to achieve the highest rate of conversion as reported in Table 4. It was found that the maximum acid conversion and product yield (99\%) was reached at the temperature of $170{ }^{\circ} \mathrm{C}$ for a reaction time of $24 \mathrm{~h}$, and conversely shorter reaction times led to the incomplete conversion of the acid. Afterwards, the authors also exploited the reaction of levunilic acid with a series of short chain alcohols, showing the good catalytic performance of halloysite in this kind of reactions.

Table 4. Optimization of experimental conditions for esterification on levulinic acid with methanol.

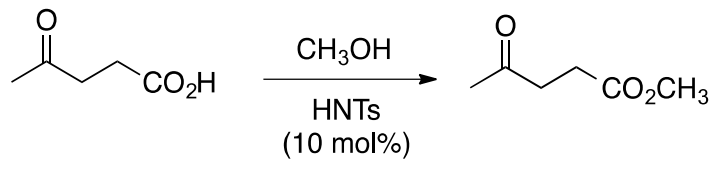

\begin{tabular}{cccc}
\hline Entry & $\mathbf{T}\left({ }^{\circ} \mathbf{C}\right)$ & $\mathbf{T}$ (h) & Yield (\%) \\
\hline 1 & 150 & 24 & 30 \\
2 & 150 & 48 & 48 \\
3 & 150 & 72 & 46 \\
4 & 160 & 48 & 68 \\
5 & 160 & 72 & 66 \\
6 & 170 & 12 & 72 \\
7 & 170 & 24 & 99 \\
\hline
\end{tabular}

${ }^{a}$ Isolated yield.

Niu et al. reported the immobilization of La-Ca bimetallic oxide onto HNTs to prepare a novel transesterification catalyst (HNTs/La-Ca) for the biodiesel production [123]. The 
catalytic activity of the HNTs/La-Ca was tested in the transesterification reaction of palm oil with methanol. In comparison to other inorganic supports used in the same reaction, the HNTs / La-Ca catalyst allowed to obtain a biodiesel yield of $97.5 \%$ by using a mass ratio of catalyst to palm oil of $7 \mathrm{wt} \%$ and a molar ratio of methanol to palm oil and oleic acid of 18 at $150{ }^{\circ} \mathrm{C}$ for $2 \mathrm{~h}$. In addition, the halloysite-based catalyst showed good recyclability and stability [123]. The stability of the developed HNTs/La-Ca catalyst was investigated in the transesterification reaction, with or without the addition of oleic acid. When the catalyst was directly reused for several consecutive runs, the authors found a slight reduction in the biodiesel yield from $98.5 \%$ to $88.7 \%$ for first and fifth cycle, demonstrating the good recyclability properties of the nanomaterial. On the contrary, the addition of oleic acid into the transesterification source, the authors assisted a decrease in the biodiesel yield after the first cycle (ca. 95\%) which drop to the $47 \%$ after five consecutive runs. Although the presence of lanthanum onto the HNTs surface guarantees the stability of the nanomaterial even at concentration of oleic acid of $5 \%$, the presence of free fatty acids poisoned the basic active sites, and thus a worsening of catalytic performances is observed [123].

Similarly, sodium aluminate $\left(\mathrm{NaAlO}_{2}\right)$ was immobilized onto HNTs by different impregnation methods [124]. Among those utilized by the authors, the most promising was the ultrasound-assisted method, which allowed us to obtain a better dispersion of the metal oxide onto HNTs. The obtained 0.4SA/ HNTs-UI nanomaterial was used as catalyst in the transesterification of palm oil with methanol, using a GA_BP neural network to predict the optimal values of reaction parameters. Based on the prediction result, the amount maximum of biodiesel produced was ca. $99 \%$, with a catalyst loading amount of ca. $9 \mathrm{wt} \%$, methanol to oil molar ratio of 17 and transesterification temperature of $65^{\circ} \mathrm{C}$.

ZnO NPs supported onto HNTs were also used as a catalyst for biodiesel production [84]. The nanomaterial was tested in the reaction between soybean oil, chosen as a model lipid and methanol in the presence of tetrabutylammonium iodide (TBAI), an additive that acted as a phase transfer agent. The experimental results showed that conversely to pristine HNTs, which showed negligible catalytic activity, the HNT@ZnO nanomaterial showed an appreciable reactivity furnishing biodiesel in a 19\% of yield, which increases to $99 \%$ in the presence of TBAI.

\section{Conclusions and Future Perspective}

In conclusion, this review shows that halloysite because of its intrinsic physicochemical properties represents a valuable resource for different purposes. The tubular morphology is the key factor for most of the applications where the adsorption and protection of active species is required. For these features, it is reasonable to assume that, like other clay minerals, HNTs could have had a relevant role in the origin of life. Up to now, for the best of our knowledge, no studies addressed this issue, but it is possible to foresee that it could be envisaged in the near future.

For catalytic purposes, the use of halloysite nanotubes results advantageous both to enhance the catalytic activity of the species loaded onto them and to develop smart catalysts for industrial applications. Over the years, it has been demonstrated that the use of HNTs as a catalyst itself reduces costs allowing to perform green reactions. These aspects show clear results when the clay is used in industrial processes such as cracking of petroleum products, biodiesel production and synthesis of pharmaceuticals scaffolds. When used as inorganic supports, HNTs give countless advantages; they avoid sintering of metal nanoparticles, act as solid and robust supports and due their large aspect/ratio and surface area and increase the local concentration of reactants to be beneficial, for example in the photocatalytic field.

Due to these features, it is realistic to foresee an extensive future use of this particular tubular clay as an efficient catalyst for different processes. The progress of scientific research will be addressed to find the best combination halloysite/catalytic species to better optimize chemical synthesis and/or to remove pollutants from the environment. 
The development of novel strategies to selectively modify the HNTs surfaces will open up the possibility to obtain more and more catalysts with improved performances.

In this context, for example, the modification of HNTs external surface with ZnO NPs allowed us to achieve a controlled polymerization of dopamine, thus acting as a template for a site-specific functionalization of HNTs [31]. This strategy could be important to immobilize metal NPs of small dimensions, which could possess improved catalytic ability.

Author Contributions: M.M. and S.R. writing-original draft preparation and writing-review and editing; S.R, conceptualization, R.N., writing-review and editing. All authors have read and agreed to the published version of the manuscript.

Funding: This research received no external funding.

Conflicts of Interest: The authors declare no conflict of interest.

\section{References}

1. Hofmann, U. On the Chemistry of Clay. Angew. Chem. 1968, 7, 681-692. [CrossRef]

2. Macewan, D.M.C. Clay Minerals as Catalysts and Adsorbents. Nature 1948, 162, 195-196. [CrossRef] [PubMed]

3. Milliken, T.H.; Oblad, A.G.; Mills, G.A. Use of Clays as Petroleum Cracking Catalysts. Clays Clay Miner. 1952, 1, $314-326$. [CrossRef]

4. Bretti, C.; Cataldo, S.; Gianguzza, A.; Lando, G.; Lazzara, G.; Pettignano, A.; Sammartano, S. Thermodynamics of Proton Binding of Halloysite Nanotubes. J. Phys. Chem. C 2016, 120, 7849-7859. [CrossRef]

5. Veerabadran, N.G.; Price, R.R.; Lvov, Y.M. Clay nanotubes for encapsulation and sustained release of drugs. Nano 2007, 2, 115-120. [CrossRef]

6. Konnova, S.A.; Sharipova, I.R.; Demina, T.A.; Osin, Y.N.; Yarullina, D.R.; Ilinskaya, O.N.; Lvov, Y.M.; Fakhrullin, R.F. Biomimetic cell-mediated three-dimensional assembly of halloysite nanotubes. Chem. Commun. 2013, 49, 4208-4210. [CrossRef]

7. Abdullayev, E.; Abbasov, V.; Tursunbayeva, A.; Portnov, V.; Ibrahimov, H.; Mukhtarova, G.; Lvov, Y. Self-healing coatings based on halloysite clay polymer composites for protection of copper alloys. ACS Appl. Mater. Interf. 2013, 5, 4464-4471. [CrossRef]

8. Abdullayev, E.; Lvov, Y. Halloysite clay nanotubes as a ceramic "skeleton" for functional biopolymer composites with sustained drug release. J. Mater. Chem. B 2013, 1, 2894-2903. [CrossRef]

9. Wu, S.; Qiu, M.; Guo, B.; Zhang, L.; Lvov, Y. Nanodot-loaded clay nanotubes as green and sustained radical scavengers for elastomer. ACS Sustain. Chem. Eng. 2017, 5, 1775-1783. [CrossRef]

10. Huang, J.; Tang, Z.H.; Zhang, X.H.; Guo, B.C. Halloysite Polymer Nanocomposites. In Developments in Clay Science; Elsevier: Amsterdam, The Netherlands, 2016; pp. 509-553.

11. Jiang, Y.; Wang, P.; Zheng, J. Use of ionic monomers to prepare halloysite polymer nanocomposites with reinforced mechanical performance. Appl. Clay Sci. 2017, 141, 248-256. [CrossRef]

12. Arcudi, F.; Cavallaro, G.; Lazzara, G.; Massaro, M.; Milioto, S.; Noto, R.; Riela, S. Selective Functionalization of Halloysite cavity by click reaction: Structured filler for enhancing mechanical properties of Bionanocomposite films. J. Phys. Chem. C 2014, 118, 15095-15101. [CrossRef]

13. Massaro, M.; Armetta, F.; Cavallaro, G.; Martino, D.F.C.; Gruttadauria, M.; Lazzara, G.; Riela, S.; D'Ischia, M. Effect of halloysite nanotubes filler on polydopamine properties. J. Colloid Interface Sci. 2019, 555, 394-402. [CrossRef] [PubMed]

14. Tang, Z.; Guo, B. Flame Retardant Polymer-Halloysite Nanocomposites. In RSC Smart Materials; RSC Publishing: Cambridge, UK, 2017; pp. 245-270.

15. Massaro, M.; Colletti, C.G.; Lazzara, G.; Guernelli, S.; Noto, R.; Riela, S. Synthesis and Characterization of Halloysite-Cyclodextrin Nanosponges for Enhanced Dyes Adsorption. ACS Sustain. Chem. Eng. 2017, 5, 3346-3352. [CrossRef]

16. Matusik, J. Halloysite for Adsorption and Pollution Remediation. In Developments in Clay Science; Elsevier: Amsterdam, The Netherlands, 2016; pp. 606-627.

17. Massaro, M.; Riela, S.; Cavallaro, G.; Colletti, C.G.; Milioto, S.; Noto, R.; Lazzara, G. Ecocompatible Halloysite/Cucurbit[8]uril Hybrid as Efficient Nanosponge for Pollutants Removal. ChemistrySelect 2016, 1, 1773-1779. [CrossRef]

18. Riahi-Madvaar, R.; Taher, M.A.; Fazelirad, H. Synthesis and characterization of magnetic halloysite-iron oxide nanocomposite and its application for naphthol green B removal. Appl. Clay Sci. 2017, 137, 101-106. [CrossRef]

19. Zhou, T.; Li, C.; Jin, H.; Lian, Y.; Han, W. Effective Adsorption/Reduction of Cr(VI) Oxyanion by Halloysite@Polyaniline Hybrid Nanotubes. ACS Appl. Mater. Interfaces 2017, 9, 6030-6043. [CrossRef]

20. Zhu, K.; Duan, Y.; Wang, F.; Gao, P.; Jia, H.; Ma, C.; Wang, C. Silane-modified halloysite $/ \mathrm{Fe}_{3} \mathrm{O}_{4}$ nanocomposites: Simultaneous removal of $\mathrm{Cr}(\mathrm{VI})$ and $\mathrm{Sb}(\mathrm{V})$ and positive effects of $\mathrm{Cr}(\mathrm{VI})$ on $\mathrm{Sb}(\mathrm{V})$ adsorption. Chem. Eng. J. 2017, 311, 236-246. [CrossRef]

21. Cavallaro, G.; Lazzara, G.; Milioto, S. Exploiting the Colloidal Stability and Solubilization Ability of Clay Nanotubes/Ionic Surfactant Hybrid Nanomaterials. J. Phys. Chem. C 2012, 116, 21932-21938. [CrossRef]

22. Cataldo, S.; Crea, F.; Massaro, M.; Milea, D.; Pettignano, A.; Riela, S. Functionalized halloysite nanotubes for enhanced removal of Hg2+ ions from aqueous solutions. Clays Clay Miner. 2021, 69, 117-127. [CrossRef] 
23. Massaro, M.; Lazzara, G.; Milioto, S.; Noto, R.; Riela, S. Covalently modified halloysite clay nanotubes: Synthesis, properties, biological and medical applications. J. Mater. Chem. B 2017, 5, 2867-2882. [CrossRef]

24. Ariga, K.; Abe, H.; Ji, Q.; Lvov, Y.M. Halloysite and Related Mesoporous Carriers for Advanced Catalysis and Drug Delivery. In RSC Smart Materials; RSC Publishing: Cambridge, UK, 2017; pp. 207-222.

25. Duce, C.; della Porta, V.; Bramanti, E.; Campanella, B.; Spepi, A.; Tiné, M.R. Loading of halloysite nanotubes with BSA, $\alpha$-Lac and $\beta$-Lg: A Fourier transform infrared spectroscopic and thermogravimetric study. Nanotechnology 2017, 28, 055706. [CrossRef] [PubMed]

26. Li, W.; Liu, D.; Zhang, H.; Correia, A.; Mäkilä, E.; Salonen, J.; Hirvonen, J.; Santos, H.A. Microfluidic assembly of a nano-in-micro dual drug delivery platform composed of halloysite nanotubes and a $\mathrm{pH}$-responsive polymer for colon cancer therapy. Acta Biomater. 2017, 48, 238-246. [CrossRef] [PubMed]

27. Minullina, R.; Tully, J.; Yendluri, R.; Lvov, Y. Halloysite Clay Nanotubes for Long Acting Controlled Release of Drugs and Proteins. In RSC Smart Materials; RSC Publishing: Cambridge, UK, 2017; pp. 354-378.

28. Yendluri, R.; Otto, D.P.; De Villiers, M.M.; Vinokurov, V.; Lvov, Y.M. Application of halloysite clay nanotubes as a pharmaceutical excipient. Int. J. Pharm. 2017, 521, 267-273. [CrossRef] [PubMed]

29. Cavallaro, G.; Lazzara, G.; Massaro, M.; Milioto, S.; Noto, R.; Parisi, F.; Riela, S. Biocompatible poly(N-isopropylacrylamide)halloysite nanotubes for thermoresponsive curcumin release. J. Phys. Chem. C 2015, 119, 8944-8951. [CrossRef]

30. Rizzo, C.; Arrigo, R.; D’Anna, F.; Di Blasi, F.; Dintcheva, N.T.; Lazzara, G.; Parisi, F.; Riela, S.; Spinelli, G.; Massaro, M. Hybrid supramolecular gels of Fmoc-F/halloysite nanotubes: Systems for sustained release of camptotheci. J. Mater. Chem. B 2017, 5, 3217-3229. [CrossRef]

31. Alfieri, M.L.; Massaro, M.; D’Ischia, M.; D’Errico, G.; Gallucci, N.; Gruttadauria, M.; Licciardi, M.; Liotta, L.F.; Nicotra, G.; Sfuncia, G.; et al. Site-specific halloysite functionalization by polydopamine: A new synthetic route for potential near infrared-activated delivery system. J. Colloid Interface Sci. 2021, 606, 1779-1791. [CrossRef]

32. Massaro, M.; Borrego-Sánchez, A.; Sánchez-Espejo, R.; Iborra, C.V.; Cavallaro, G.; García-Villén, F.; Guernelli, S.; Lazzara, G.; Miele, D.; Sainz-Díaz, C.I.; et al. Ciprofloxacin carrier systems based on hectorite/halloysite hybrid hydrogels for potential wound healing applications. Appl. Clay Sci. 2021, 215, 106310. [CrossRef]

33. Massaro, M.; Barone, G.; Barra, V.; Cancemi, P.; Di Leonardo, A.; Grossi, G.; Celso, F.L.; Schenone, S.; Iborra, C.V.; Riela, S. Pyrazole[3,4-d]pyrimidine derivatives loaded into halloysite as potential CDK inhibitors. Int. J. Pharm. 2021, 599, 120281. [CrossRef]

34. Massaro, M.; Colletti, C.G.; Guernelli, S.; Lazzara, G.; Liu, M.; Nicotra, G.; Noto, R.; Parisi, F.; Pibiri, I.; Spinella, C.; et al. Photoluminescent hybrid nanomaterials from modified halloysite nanotubes. J. Mater. Chem. C 2018, 6, 7377-7384. [CrossRef]

35. Riela, S.; Barattucci, A.; Barreca, D.; Campagna, S.; Cavallaro, G.; Lazzara, G.; Massaro, M.; Pizzolanti, G.; Salerno, T.M.; Bonaccorsi, P.; et al. Boosting the properties of a fluorescent dye by encapsulation into halloysite nanotubes. Dyes Pigm. 2021, 187, 109094. [CrossRef]

36. Pasbakhsh, P.; Ismail, H.; Fauzi, M.A.; Abu Bakar, A. Influence of maleic anhydride grafted ethylene propylene diene monomer (MAH-g-EPDM) on the properties of EPDM nanocomposites reinforced by halloysite nanotubes. Polym. Test. 2009, 28, 548-559. [CrossRef]

37. Yuan, P.; Tan, D.; Annabi-Bergaya, F. Properties and applications of halloysite nanotubes: Recent research advances and future prospects. Appl. Clay Sci. 2015, 112, 75-93. [CrossRef]

38. Massaro, M.; Cavallaro, G.; Colletti, C.G.; Lazzara, G.; Milioto, S.; Noto, R.; Riela, S. Chemical modification of halloysite nanotubes for controlled loading and release. J. Mater. Chem. B 2018, 6, 3415-3433. [CrossRef] [PubMed]

39. Wan, X.; Zhan, Y.; Long, Z.; Zeng, G.; He, Y. Core@double-shell structured magnetic halloysite nanotube nano-hybrid as efficient recyclable adsorbent for methylene blue removal. Chem. Eng. J. 2017, 330, 491-504. [CrossRef]

40. Tae, J.-W.; Jang, B.-S.; Kim, J.-R.; Kim, I.; Park, D.-W. Catalytic degradation of polystyrene using acid-treated halloysite clays. Solid State Ionics 2004, 172, 129-133. [CrossRef]

41. Machado, G.S.; de Castro, K.A.D.; Wypych, F.; Nakagaki, S. Immobilization of metalloporphyrins into nanotubes of natural halloysite toward selective catalysts for oxidation reactions. J. Mol. Catal. A Chem. 2008, 283, 99-107. [CrossRef]

42. Machado, G.S.; de Lima, O.J.; Ciuffi, K.J.; Wypych, F.; Nakagaki, S. Iron(iii) porphyrin supported on metahalloysite: An efficient and reusable catalyst for oxidation reactions. Catal. Sci. Technol. 2013, 3, 1094-1101. [CrossRef]

43. Massaro, M.; Colletti, C.G.; Lazzara, G.; Milioto, S.; Noto, R.; Riela, S. Halloysite nanotubes as support for metal-based catalysts. J. Mater. Chem. A 2017, 5, 13276-13293. [CrossRef]

44. Zhai, R.; Zhang, B.; Liu, L.; Xie, Y.; Zhang, H.; Liu, J. Immobilization of enzyme biocatalyst on natural halloysite nanotubes. Catal. Commun. 2010, 12, 259-263. [CrossRef]

45. Chen, S.; Li, J.; Zhang, Y.; Zhang, D.; Zhu, J. Effect of preparation method on halloysite supported cobalt catalysts for FischerTropsch synthesis. J. Nat. Gas Chem. 2012, 21, 426-430. [CrossRef]

46. Barrientos-Ramírez, S.; Oca-Ramírez, G.M.D.; Ramos-Fernández, E.V.; Sepúlveda-Escribano, A.; Pastor-Blas, M.M.; GonzálezMontiel, A. Surface modification of natural halloysite clay nanotubes with aminosilanes. Application as catalyst supports in the atom transfer radical polymerization of methyl methacrylate. Appl. Catal. A Gen. 2011, 406, 22-33. [CrossRef]

47. Jiang, J.; Zhang, Y.; Yan, L.; Jiang, P. Epoxidation of soybean oil catalyzed by peroxo phosphotungstic acid supported on modified halloysite nanotubes. Appl. Surf. Sci. 2012, 258, 6637-6642. [CrossRef] 
48. Zou, M.; Du, M.; Zhu, H.; Xu, C.; Fu, Y. Green synthesis of halloysite nanotubes supported Ag nanoparticles for photocatalytic decomposition of methylene blue. J. Phys. D Appl. Phys. 2012, 45, 325302. [CrossRef]

49. Wang, L.; Chen, J.; Rudolph, V.; Zhu, Z. Nanotubules-supported Ru nanoparticles for preferential CO oxidation in $\mathrm{H}_{2}$-rich stream. Adv. Powder Technol. 2012, 23, 465-471. [CrossRef]

50. Wang, L.; Chen, J.; Ge, L.; Rudolph, V.; Zhu, Z. Halloysite nanotube supported Ru nanocatalysts synthesized by the inclusion of preformed $\mathrm{Ru}$ nanoparticles for preferential oxidation of $\mathrm{CO}$ in $\mathrm{H}_{2}$-rich atmosphere. J. Phys. Chem. C 2013, 117, $4141-4151$. [CrossRef]

51. Zhang, Y.; Pan, J.; Gan, M.; Ou, H.; Yan, Y.; Shi, W.; Yu, L. Acid-chromic chloride functionalized natural clay-particles for enhanced conversion of one-pot cellulose to 5-hydroxymethylfurfural in ionic liquids. RSC Adv. 2014, 4, 11664-11672. [CrossRef]

52. Sahiner, N.; Sengel, S.B. Various amine functionalized halloysite nanotube as efficient metal free catalysts for $\mathrm{H}_{2}$ generation from sodium borohydride methanolysis. Appl. Clay Sci. 2017, 146, 517-525. [CrossRef]

53. Sahiner, N.; Sengel, S.B. Environmentally benign halloysite clay nanotubes as alternative catalyst to metal nanoparticles in $\mathrm{H}_{2}$ production from methanolysis of sodium borohydride. Fuel Process. Technol. 2017, 158, 1-8. [CrossRef]

54. Sidorenko, A.Y.; Kravtsova, A.V.; Aho, A.; Heinmaa, I.; Volcho, K.P.; Salakhutdinov, N.F.; Agabekov, V.; Murzin, D.Y. Acidmodified Halloysite Nanotubes as a Stereoselective Catalyst for Synthesis of $2 \mathrm{H}$-Chromene Derivatives by the Reaction of Isopulegol with Aldehydes. ChemCatChem 2018, 10, 3950-3954. [CrossRef]

55. Sidorenko, A.; Kravtsova, A.; Aho, A.; Heinmaa, I.; Wärnå, J.; Pazniak, H.; Volcho, K.; Salakhutdinov, N.; Murzin, D.; Agabekov, V. Highly selective Prins reaction over acid-modified halloysite nanotubes for synthesis of isopulegol-derived $2 \mathrm{H}$-chromene compounds. J. Catal. 2019, 374, 360-377. [CrossRef]

56. Sidorenko, A.Y.; Kravtsova, A.V.; Il'ina, I.V.; Wärnå, J.; Korchagina, D.V.; Gatilov, Y.V.; Volcho, K.P.; Salakhutdinov, N.F.; Murzin, D.Y.; Agabekov, V.E. Clay nanotubes catalyzed solvent-free synthesis of octahydro-2H-chromenols with pharmaceutical potential from (-)-isopulegol and ketones. J. Catal. 2019, 380, 145-152. [CrossRef]

57. Sidorenko, A.Y.; Kurban, Y.M.; Il'ina, I.V.; Li-Zhulanov, N.S.; Korchagina, D.V.; Ardashov, O.V.; Wärnå, J.; Volcho, K.P.; Salakhutdinov, N.F.; Murzin, D.Y.; et al. Catalytic synthesis of terpenoid-derived hexahydro- $2 H$-chromenes with analgesic activity over halloysite nanotubes. Appl. Catal. A Gen. 2021, 618, 118144. [CrossRef]

58. Li-Zhulanov, N.; Mäki-Arvela, P.; Laluc, M.; Peixoto, A.F.; Kholkina, E.; Sandberg, T.; Aho, A.; Volcho, K.; Salakhutdinov, N.; Freire, C.; et al. Prins cyclization of (-)-isopulegol with benzaldehyde for production of chromenols over organosulfonic clays. Mol. Catal. 2019, 478, 110569. [CrossRef]

59. Sidorenko, A.Y.; Kravtsova, A.V.; Mäki-Arvela, P.; Aho, A.; Sandberg, T.; Il'ina, I.V.; Li-Zhulanov, N.S.; Korchagina, D.V.; Volcho, K.P.; Salakhutdinov, N.F.; et al. Synthesis of isobenzofuran derivatives from renewable 2-carene over halloysite nanotubes. Mol. Catal. 2020, 490, 110974. [CrossRef]

60. Samadani, M.; Asadi, B.; Mohammadpoor-Baltork, I.; Mirkhani, V.; Tangestaninejad, S.; Moghadam, M. Triazine bis(pyridinium) hydrogen sulfate ionic liquid immobillized on functionalized halloysite nanotubes as an efficient catalyst for one-pot synthesis of naphthopyranopyrimidines. RSC Adv. 2021, 11, 11976-11983. [CrossRef]

61. Liu, M.; Zhang, Y.; Zhu, E.; Jin, P.; Wang, K.; Zhao, J.; Li, C.; Yan, Y. Facile Synthesis of Halloysite Nanotubes-Supported Acidic Metal-Organic Frameworks with Tunable Acidity for Efficient Fructose Dehydration to 5-Hydroxymethylfurfural. ChemistrySelect 2017, 2, 10413-10419. [CrossRef]

62. Fan, X.; Hu, M.; Li, S.; Zhai, Q.; Wang, F.; Jiang, Y. Charge controlled immobilization of chloroperoxidase on both inner/outer wall of NHT: Improved stability and catalytic performance in the degradation of pesticide. Appl. Clay Sci. 2018, 163, 92-99. [CrossRef]

63. Sillu, D.; Agnihotri, S. Cellulase Immobilization onto Magnetic Halloysite Nanotubes: Enhanced Enzyme Activity and Stability with High Cellulose Saccharification. ACS Sustain. Chem. Eng. 2020, 8, 900-913. [CrossRef]

64. Wu, Z.; Yuan, X.; Zhang, J.; Wang, H.; Jiang, L.; Zeng, G. Photocatalytic Decontamination of Wastewater Containing Organic Dyes by Metal-Organic Frameworks and their Derivatives. ChemCatChem 2016, 9, 41-64. [CrossRef]

65. Li, X.; Yao, C.; Lu, X.; Hu, Z.; Yin, Y.; Ni, C. Halloysite-CeO $2-\mathrm{AgBr}$ nanocomposite for solar light photodegradation of methyl orange. Appl. Clay Sci. 2015, 104, 74-80. [CrossRef]

66. Xing, W.; Ni, L.; Huo, P.; Lu, Z.; Liu, X.; Luo, Y.; Yan, Y. Preparation high photocatalytic activity of CdS/halloysite nanotubes (HNTs) nanocomposites with hydrothermal method. Appl. Surf. Sci. 2012, 259, 698-704. [CrossRef]

67. Li, J.; Zhou, M.; Ye, Z.; Wang, H.; Ma, C.; Huo, P.; Yan, Y. Enhanced photocatalytic activity of g-C $3 \mathrm{~N}_{4}-\mathrm{ZnO} / \mathrm{HNT}$ composite heterostructure photocatalysts for degradation of tetracycline under visible light irradiation. RSC Adv. 2015, 5, 91177-91189. [CrossRef]

68. Li, C.; Zhou, T.; Zhu, T.; Li, X. Enhanced visible light photocatalytic activity of polyaniline-crystalline $\mathrm{TiO}_{2}-$ halloysite composite nanotubes by tuning the acid dopant in the preparation. RSC Adv. 2015, 5, 98482-98491. [CrossRef]

69. Jia, L.; Zhou, T.; Xu, J.; Li, X.; Dong, K.; Huang, J.; Xu, Z. The Enhanced Catalytic Activities of Asymmetric Au-Ni Nanoparticle Decorated Halloysite-Based Nanocomposite for the Degradation of Organic Dyes. Nanoscale Res. Lett. 2016, 11, 72. [CrossRef] [PubMed]

70. Zheng, P.; Du, Y.; Ma, X. Selective fabrication of iron oxide particles in halloysite lumen. Mater. Chem. Phys. 2015, 151, 14-17. [CrossRef]

71. Xianchu, L.; Xiuyun, C.; Aiping, W.; Feiyu, K. Microstructure and Photocatalytic Decomposition of Methylene Blue by TiO ${ }_{2-}$ Mounted Halloysite, a Natural Tubular Mineral. Acta Geol. Sin. 2010, 80, 278-284. [CrossRef] 
72. Du, Y.; Zheng, P. Adsorption and photodegradation of methylene blue on $\mathrm{TiO}_{2}$-halloysite adsorbents. Korean J. Chem. Eng. 2014, 31, 2051-2056. [CrossRef]

73. Jiang, L.; Huang, Y.; Liu, T. Enhanced visible-light photocatalytic performance of electrospun carbon-doped $\mathrm{TiO}_{2} / \mathrm{halloysite}$ nanotube hybrid nanofibers. J. Colloid Interface Sci. 2015, 439, 62-68. [CrossRef]

74. Zhang, Y.; Ouyang, J.; Yang, H. Metal oxide nanoparticles deposited onto carbon-coated halloysite nanotubes. Appl. Clay Sci. 2014, 95, 252-259. [CrossRef]

75. Li, X.; Zhu, W.; Yan, X.; Lu, X.; Yao, C.; Ni, C. Hierarchical $\mathrm{La}_{0.7} \mathrm{Ce}_{0.3} \mathrm{FeO}_{3} /$ halloysite nanocomposite for photocatalytic degradation of antibiotics. Appl. Phys. A 2016, 122, 723. [CrossRef]

76. Szczepanik, B.; Rogala, P.; Słomkiewicz, P.M.; Banaś, D.; Kubala-Kukuś, A.; Stabrawa, I. Synthesis, characterization and photocatalytic activity of $\mathrm{TiO}_{2}$-halloysite and $\mathrm{Fe}_{2} \mathrm{O}_{3}$-halloysite nanocomposites for photodegradation of chloroanilines in water. Appl. Clay Sci. 2017, 149, 118-126. [CrossRef]

77. Peng, H.; Wu, D.; Wan, H.; Jia, L.; Chen, G.; Li, J.; Cao, Y.; Liu, X.; Ma, R. Facile synthesis and characterization of halloysite@W $18 \mathrm{O}_{49}$ nanocomposite with enhanced photocatalytic properties. Appl. Clay Sci. 2019, 183, 105319. [CrossRef]

78. Zhang, D.; Cui, Y.; Yang, G.; Liu, M.; Zhu, G.; Sheng, X.; Deng, F.; Zhou, N.; Zhang, X.; Wei, Y. Mussel-inspired fabrication of halloysite nanotube-based magnetic composites as catalysts for highly efficient degradation of organic dyes. Appl. Clay Sci. 2020, 198, 105835. [CrossRef]

79. Lee, J.; Seong, S.; Jin, S.; Jeong, Y.; Noh, J. Synergetic photocatalytic-activity enhancement of lanthanum doped $\mathrm{TiO}_{2}$ on halloysite nanocomposites for degradation of organic dye. J. Ind. Eng. Chem. 2021, 100, 126-133. [CrossRef]

80. Das, S.; Jana, S. A tubular nanoreactor directing the formation of in situ iron oxide nanorods with superior photocatalytic activity. Environ. Sci. Nano 2017, 4, 596-603. [CrossRef]

81. Hochbaum, A.I.; Yang, P. Semiconductor Nanowires for Energy Conversion. Chem. Rev. 2010, 110, 527-546. [CrossRef]

82. Zeng, X.; Wang, Q.; Wang, H.; Yang, Y. Catalytically active silver nanoparticles loaded in the lumen of halloysite nanotubes via electrostatic interactions. J. Mater. Sci. 2017, 52, 8391-8400. [CrossRef]

83. Zhang, M.; Su, X.; Ma, L.; Khan, A.; Wang, L.; Wang, J.; Maloletnev, A.; Yang, C. Promotion effects of halloysite nanotubes on catalytic activity of $\mathrm{Co}_{3} \mathrm{O}_{4}$ nanoparticles toward reduction of 4-nitrophenol and organic dyes. J. Hazard. Mater. 2021, 403,123870 [CrossRef]

84. Massaro, M.; Casiello, M.; D’Accolti, L.; Lazzara, G.; Nacci, A.; Nicotra, G.; Noto, R.; Pettignano, A.; Spinella, C.; Riela, S. One-pot synthesis of $\mathrm{ZnO}$ nanoparticles supported on halloysite nanotubes for catalytic applications. Appl. Clay Sci. 2020, $189,105527$. [CrossRef]

85. Stavitskaya, A.V.; Novikov, A.A.; Kotelev, M.S.; Kopitsyn, D.S.; Rozhina, E.V.; Ishmukhametov, I.R.; Fakhrullin, R.F.; Ivanov, E.V.; Lvov, Y.M.; Vinokurov, V.A. Fluorescence and Cytotoxicity of Cadmium Sulfide Quantum Dots Stabilized on Clay Nanotubes. Nanomaterials 2018, 8, 391. [CrossRef]

86. Vinokurov, V.A.; Stavitskaya, A.V.; Ivanov, E.V.; Gushchin, P.; Kozlov, D.V.; Kurenkova, A.Y.; Kolinko, P.A.; Kozlova, E.A.; Lvov, Y.M. Halloysite Nanoclay Based CdS Formulations with High Catalytic Activity in Hydrogen Evolution Reaction under Visible Light Irradiation. ACS Sustain. Chem. Eng. 2017, 5, 11316-11323. [CrossRef]

87. Stavitskaya, A.V.; Kozlova, E.A.; Kurenkova, A.Y.; Glotov, A.P.; Selischev, D.S.; Ivanov, E.V.; Kozlov, D.V.; Vinokurov, V.A.; Fakhrullin, R.F.; Lvov, Y.M. Ru/CdS Quantum Dots Templated on Clay Nanotubes as Visible-Light-Active Photocatalysts: Optimization of S/Cd Ratio and Ru Content. Chem. Eur. J. 2020, 26, 13085-13092. [CrossRef] [PubMed]

88. Wei, G.; Liu, P.; Chen, D.; Chen, T.; Liang, X.; Chen, H. Activity of manganese oxides supported on halloysite towards the thermal catalytic oxidation of formaldehyde: Constraint from the manganese precursor. Appl. Clay Sci. 2019, 182, 105280. [CrossRef]

89. Vinokurov, V.; Stavitskaya, A.; Glotov, A.; Ostudin, A.; Sosna, M.; Gushchin, P.; Darrat, Y.; Lvov, Y. Halloysite nanotube-based cobalt mesocatalysts for hydrogen production from sodium borohydride. J. Solid State Chem. 2018, 268, 182-189. [CrossRef]

90. Ouyang, J.; Zhao, Z.; Yang, H.; Zhang, Y.; Tang, A. Large-scale synthesis of sub-micro sized halloysite-composed CZA with enhanced catalysis performances. Appl. Clay Sci. 2018, 152, 221-229. [CrossRef]

91. Kang, L.; Han, L.; He, J.; Li, H.; Yan, T.; Chen, G.; Zhang, J.; Shi, L.; Zhang, D. Improved NOx Reduction in the Presence of $\mathrm{SO}_{2}$ by Using $\mathrm{Fe}_{2} \mathrm{O}_{3}$-Promoted Halloysite-Supported $\mathrm{CeO}_{2}-\mathrm{WO}_{3}$ Catalysts. Environ. Sci. Technol. 2019, 53, 938-945. [CrossRef]

92. Chen, L.; Wang, Q.; Wang, X.; Cong, Q.; Ma, H.; Guo, T.; Li, S.; Li, W. High-performance $\mathrm{CeO}_{2} /$ halloysite hierarchical catalysts with promotional redox property and acidity for the selective catalytic reduction of $\mathrm{NO}$ with $\mathrm{NH}_{3}$. Chem. Eng. J. 2020, 390, 124251. [CrossRef]

93. Deb, A.K.; Biswas, B.; Goswami, N.; Hilder, E.F.; Naidu, R.; Rahman, M.M. Synthesis of environmentally benign ultra-small copper nanoclusters-halloysite composites and their catalytic performance on contrasting azo dyes. Appl. Surf. Sci. 2021, 546, 149122. [CrossRef]

94. Baruah, M.J.; Sharma, M.; Das, B.; Saikia, P.; Saikia, L.; Roy, S.; Karunakar, G.V.; Bhattacharyya, P.K.; Bania, K.K. Boosting multiple photo-assisted and temperature controlled reactions with a single redox-switchable catalyst: Solvents as internal substrates and reducing agent. J. Catal. 2020, 388, 104-121. [CrossRef]

95. Ataee-Kachouei, T.; Nasr-Esfahani, M.; Mohammadpoor-Baltork, I.; Mirkhani, V.; Moghadam, M.; Tangestaninejad, S.; Notash, B. $\mathrm{Ce}(\mathrm{IV})$ immobilized on halloysite nanotube-functionalized dendrimer (Ce(IV)-G2): A novel and efficient dendritic catalyst for the synthesis of pyrido[3,2-c]coumarin derivatives. Appl. Organomet. Chem. 2020, 34, e5948. [CrossRef] 
96. Vinokurov, V.; Glotov, A.; Chudakov, Y.; Stavitskaya, A.; Ivanov, E.; Gushchin, P.; Zolotukhina, A.; Maximov, A.; Karakhanov, E.; Lvov, Y. Core/Shell Ruthenium-Halloysite Nanocatalysts for Hydrogenation of Phenol. Ind. Eng. Chem. Res. 2017, 56, 14043-14052. [CrossRef]

97. Glotov, A.; Novikov, A.; Stavitskaya, A.; Nedolivko, V.; Kopitsyn, D.; Kuchierskaya, A.; Ivanov, E.; Stytsenko, V.; Vinokurov, V.; Lvov, Y. Nanoreactors based on hydrophobized tubular aluminosilicates decorated with ruthenium: Highly active and stable catalysts for aromatics hydrogenation. Catal. Today 2021, 378, 33-42. [CrossRef]

98. Torres-Luna, J.A.; Moreno, S.; Molina, R.; Carriazo, J.G. Comparison of the Catalytic Performance of Ni, Mo, and Ni-Mo Impregnated on Acid Halloysite Nanotubes in the n-Decane Hydroconversion. Energy Fuels 2019, 33, 12647-12655. [CrossRef]

99. Maleki, A.; Hajizadeh, Z.; Salehi, P. Mesoporous halloysite nanotubes modified by $\mathrm{CuFe}_{2} \mathrm{O}_{4}$ spinel ferrite nanoparticles and study of its application as a novel and efficient heterogeneous catalyst in the synthesis of pyrazolopyridine derivatives. Sci. Rep. 2019, 9, 552. [CrossRef]

100. Peng, H.; Zhang, D.; Liu, X.; Tang, W.; Wan, H.; Xiong, H.; Ma, R. Facile synthesis and characterization of core-shell structured $\mathrm{Ag}_{3} \mathrm{PO}_{4} @ \mathrm{Hal}$ nanocomposites for enhanced photocatalytic properties. Appl. Clay Sci. 2017, 141, 132-137. [CrossRef]

101. Zieba, M.; Hueso, J.L.; Arruebo, M.; Martínez, G.; Santamaría, J. Gold-coated halloysite nanotubes as tunable plasmonic platforms. New J. Chem. 2014, 38, 2037-2042. [CrossRef]

102. Fu, X.; Ding, Z.; Zhang, X.; Weng, W.; Xu, Y.; Liao, J.; Xie, Z. Preparation of halloysite nanotube-supported gold nanocomposite for solvent-free oxidation of benzyl alcohol. Nanoscale Res. Lett. 2014, 9, 282. [CrossRef]

103. Philip, A.; Lihavainen, J.; Keinänen, M.; Pakkanen, T.T. Gold nanoparticle-decorated halloysite nanotubes-Selective catalysts for benzyl alcohol oxidation. Appl. Clay Sci. 2017, 143, 80-88. [CrossRef]

104. Massaro, M.; Colletti, C.G.; Fiore, B.; La Parola, V.; Lazzara, G.; Guernelli, S.; Zaccheroni, N.; Riela, S. Gold nanoparticles stabilized by modified halloysite nanotubes for catalytic applications. Appl. Organomet. Chem. 2019, 33, e4665. [CrossRef]

105. Yu, J.; Niedenthal, W.; Smarsly, B.M.; Natile, M.M.; Huang, Y.; Carraro, M. Au nanoparticles supported on piranha etched halloysite nanotubes for highly efficient heterogeneous catalysis. Appl. Surf. Sci. 2021, 546, 149100. [CrossRef]

106. Tsoufis, T.; Katsaros, F.; Kooi, B.; Bletsa, E.; Papageorgiou, S.; Deligiannakis, Y.; Panagiotopoulos, I. Halloysite nanotube-magnetic iron oxide nanoparticle hybrids for the rapid catalytic decomposition of pentachlorophenol. Chem. Eng. J. 2017, 313, 466-474. [CrossRef]

107. Daraie, M.; Heravi, M.M.; Rangraz, Y.; Besharati, Z. Pd NPs supported on halloysite functionalized with Schiff base as an efficient catalyst for Sonogashira reaction. Sci. Rep. 2021, 11, 6223. [CrossRef] [PubMed]

108. Sadjadi, S. Palladium nanoparticles immobilized on cyclodextrin-decorated halloysite nanotubes: Efficient heterogeneous catalyst for promoting copper- and ligand-free Sonogashira reaction in water-ethanol mixture. Appl. Organomet. Chem. 2018, 32 , e4211. [CrossRef]

109. Dedzo, G.K.; Ngnie, G.; Detellier, C. PdNP Decoration of Halloysite Lumen via Selective Grafting of Ionic Liquid onto the Aluminol Surfaces and Catalytic Application. ACS Appl. Mater. Interfaces 2016, 8, 4862-4869. [CrossRef] [PubMed]

110. Li, W.-J.; Wey, M.-Y. Core-shell design and well-dispersed Pd particles for three-way catalysis: Effect of halloysite nanotubes functionalized with Schiff base. Sci. Total Environ. 2019, 675, 397-407. [CrossRef] [PubMed]

111. Ahmad, Y.H.; Mohamed, A.T.; Hassan, W.M.; Soliman, A.; Mahmoud, K.A.; Aljaber, A.S.; Al-Qaradawi, S.Y. Bimetallic palladiumsupported halloysite nanotubes for low temperature CO oxidation: Experimental and DFT insights. Appl. Surf. Sci. 2019, 493, 70-80. [CrossRef]

112. Corbet, J.-P.; Mignani, G.R. Selected Patented Cross-Coupling Reaction Technologies. Cheminform 2006, 106, 2651-2710.

113. Hong, M.C.; Ahn, H.; Choi, M.C.; Lee, Y.; Kim, J.; Rhee, H. Pd nanoparticles immobilized on PNIPAM-halloysite: Highly active and reusable catalyst for Suzuki-Miyaura coupling reactions in water. Appl. Organomet. Chem. 2014, 28, 156-161. [CrossRef]

114. Massaro, M.; Riela, S.; Lazzara, G.; Gruttadauria, M.; Milioto, S.; Noto, R. Green conditions for the Suzuki reaction using microwave irradiation and a new HNT-supported ionic liquid-like phase (HNT-SILLP) catalyst. Appl. Organomet. Chem. 2014, 28, 234-238. [CrossRef]

115. Massaro, M.; Colletti, C.G.; Buscemi, G.; Cataldo, S.; Guernelli, S.; Lazzara, G.; Liotta, L.F.; Parisi, F.; Pettignano, A.; Riela, S. Palladium nanoparticles immobilized on halloysite nanotubes covered by a multilayer network for catalytic applications. New $\mathrm{J}$. Chem. 2018, 42, 13938-13947. [CrossRef]

116. Massaro, M.; Riela, S.; Cavallaro, G.; Colletti, C.; Milioto, S.; Noto, R.; Parisi, F.; Lazzara, G. Palladium supported on Halloysitetriazolium salts as catalyst for ligand free Suzuki cross-coupling in water under microwave irradiation. J. Mol. Catal. A Chem. 2015, 408, 12-19. [CrossRef]

117. Baran, N.Y.; Baran, T.; Menteş, A. Design of highly robust halloysite nanoclay supported palladium complex as a highly active heterogeneous catalyst for construction of biaryls. Appl. Clay Sci. 2019, 181, 105225. [CrossRef]

118. Bahri-Laleh, N.; Sadjadi, S.; Poater, A. Pd immobilized on dendrimer decorated halloysite clay: Computational and experimental study on the effect of dendrimer generation, Pd valance and incorporation of terminal functionality on the catalytic activity. $J$. Colloid Interface Sci. 2018, 531, 421-432. [CrossRef] [PubMed]

119. Ahmad, Y.H.; Mohamed, A.T.; Al-Qaradawi, S.Y. Exploring halloysite nanotubes as catalyst support for methane combustion: Influence of support pretreatment. Appl. Clay Sci. 2021, 201, 105956. [CrossRef]

120. Zheng, Y.; Wang, L.; Zhong, F.; Cai, G.; Xiao, Y.; Jiang, L. Site-Oriented Design of High-Performance Halloysite-Supported Palladium Catalysts for Methane Combustion. Ind. Eng. Chem. Res. 2020, 59, 5636-5647. [CrossRef] 
121. Zatta, L.; da Costa Gardolinski, J.E.F.; Wypych, F. Raw halloysite as reusable heterogeneous catalyst for esterification of lauric acid. Appl. Clay Sci. 2011, 51, 165-169. [CrossRef]

122. Hamdi, J.; Diehl, B.N.; Kilgore, K.; Lomenzo, S.A.; Trudell, M.L. Halloysite-Catalyzed Esterification of Bio-Mass Derived Acids. ACS Omega 2019, 4, 19437-19441. [CrossRef]

123. Lin, T.; Zhao, S.; Niu, S.; Lyu, Z.; Han, K.; Hu, X. Halloysite nanotube functionalized with La-Ca bimetallic oxides as novel transesterification catalyst for biodiesel production with molecular simulation. Energy Convers. Manag. 2020, 220, 113138. [CrossRef]

124. Ning, Y.; Niu, S.; Wang, Y.; Zhao, J.; Lu, C. Sono-modified halloysite nanotube with $\mathrm{NaAlO}_{2}$ as novel heterogeneous catalyst for biodiesel production: Optimization via GA_BP neural network. Renew. Energy 2021, 175, 391-404. [CrossRef] 